Original paper

\title{
Early Carboniferous $P-T$ path from the Upper Gneiss Unit of Haut-Allier (French Massif Central) - reconstructed by geothermobarometry and EMP-Th-U-Pb monazite dating
}

\author{
Bernhard SCHULZ*
}

Institute of Mineralogy, Department Economic Geology and Petrology, TU Bergakademie Freiberg, Brennhausgasse 14, D-09596 Freiberg/Saxony, Germany; Bernhard.Schulz@mineral.tu-freiberg.de

* Corresponding author

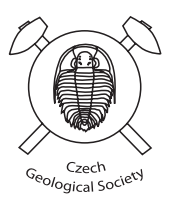

In the Haut-Allier region (French Massif Central), a Variscan inverted metamorphic sequence is made up by crustal nappes. A high-grade Upper Gneiss Unit (UGU) was thrusted over a Lower Gneiss Unit (LGU) and an amphibolite-facies para-autochthonous Micaschist Unit (MU). Growth-zoned garnets with distinct Mn-Mg-Fe-Ca and trace-element zonation trends occur in kyanite garnet gneisses at Agnat (UGU). The porphyroblasts have been characterised by automated energy-dispersive X-ray spectral mapping with SEM, by electron microprobe and LA-ICPMS analyses. Microstructurally-controlled geothermobarometry based on cation exchange and net transfer reactions was used to reconstruct a syn-deformational and clockwise $\mathrm{P}-\mathrm{T}$ path for garnet crystallization in the UGU. The P-T path passed maximal pressures at $700^{\circ} \mathrm{C} / 13 \mathrm{kbar}$ and then maximal temperatures at $\sim 800^{\circ} \mathrm{C} / 11 \mathrm{kbar}$ in the stability field of kyanite $+\mathrm{K}$-feldspar. The final stage of the $\mathrm{P}-\mathrm{T}$ path is a marked decompression from 10 to $5 \mathrm{kbar}$ at $700-750^{\circ} \mathrm{C}$. The timing of this $\mathrm{P}-\mathrm{T}$ evolution in the UGU has been constrained by electron-microprobe Th-U-Pb monazite dating (CHIME). A detailed interpretation of ages and Y-contents of monazites enclosed in a syncrystalline-rotated Mg-rich garnet allowed to relate a marked pressure decrease along a late stage of the P-T path to 330 Ma. Simple 1D forward numerical modeling with variations of vertical velocity and geothermal gradient confirmed that the onset of monazite crystallization at $\sim 360$ Ma should give a maximal age of the early P-T evolution. A distinct group of Y-rich monazites could be the relic of this Late Devonian event. Most monazite ages from the UGU, the LGU and the MU in the Haut-Allier region range between 360 and $320 \mathrm{Ma}$, with isochrons for single samples giving ages from 332 to $338 \mathrm{Ma}$. The prograde-retrograde P-T-t evolution in the UGU appears as an independent Early Carboniferous metamorphic cycle, which was related to a continental collision. It post-dated a Silurian HP-(UHP) event and a subsequent Early Devonian migmatization in the UGU.

Keywords: P-T-t-path, Th-U-Pb monazite dating, garnet zoning, geothermobarometry, Variscan orogeny

Received: 24 February 2014; accepted: 21 October 2014; handling editor: F. Finger

The online version of this article (doi: 10.3190/jgeosci.178) contains supplementary electronic material.

\section{Introduction}

Structural, petrological and geophysical data have shown that the French Massif Central was part of the Variscan tectono-metamorphic history which involved subduction and continental collision of Laurussia with Peri-Gondwana and Gondwana-derived microcontinents (Armorica, Avalonia) in between (Burg et al. 1984; Ledru et al. 1989; Santallier et al. 1994; Matte 2001; Faure et al. 2005, 2008, 2009; Kroner and Romer 2013). Five principal nappe units (from top to bottom: Brévenne and Génis, Thiviers-Payzac, Upper Gneiss, Lower Gneiss, and Para-Autochthonous units) have been identified in the internal part of the French Massif Central, as outlined in Ledru et al. (1994) and Faure et al. (2005, 2009). Some of the allochthonous units (Fig. 1a) can be traced to the W into the South Armorican Domain (Ballèvre et al. 2009). This nappe pile was thrusted over an unknown Upper Proterozoic basement with a Pre-Carboniferous cover in some parts (Faure et al. 2009). Some of the nappes, especially the
Upper Gneiss Unit, preserve record of several metamorphic stages: (1) a Late Silurian 430-390 Ma high-pressure (HP) or ultra high-pressure (UHP) metamorphic event, (2) a Devonian (385-380 Ma) high-grade metamorphism with migmatization and (3) a Late Devonian to Early Carboniferous (360-350 Ma) amphibolite-facies to high-grade metamorphism (Faure et al. 1997, 2005, 2009).

Contrasting thermotectonic models have been proposed to explain these metamorphic stages. A two-cycle tectonometamorphic evolution model combined the events (1) and (2) into a first cycle (Eo-Variscan), whereas the event (3) was ascribed to a second orogenic cycle (Faure et al. 1997; Roig and Faure 2000; Pin and Paquette 2002; Faure et al. 2005; Bellot and Roig 2007; Faure et al. 2009). Some of the main arguments for this model are a Devonian back-arc spreading, the observation that HP rocks were already exhumed before the Middle Devonian in the Morvan region (Faure et al. 1997), and a Middle Devonian anatexis in the Upper Gneiss Unit (Duthou et al. 1994; Faure et al. 2008). In contrast, one-cycle mod- 
els (Brun and Burg 1982; Burg et al. 1987; Ledru et al. 1994; Matte 2001) involved a single $\mathrm{P}-\mathrm{T}-\mathrm{t}$ path for all tectonic units during a long and progressive subduction, followed by exhumation of the HP rocks and a collision with migrating directions of thrusting.

This paper reports detailed chemical model (CHIME) $\mathrm{Th}-\mathrm{U}-\mathrm{Pb}$ monazite ages and geothermobarometric data of a prograde-retrograde $\mathrm{P}-\mathrm{T}$ path section from a kyanite garnet gneiss in the Upper Gneiss Unit of the Haut-Allier area. A combination of conventional geothermobarometric data with monazite ages and mineral chemistry is used to reconstruct the P-T-t evolution. Simple forward numerical modeling further constrains the $\mathrm{P}-\mathrm{T}-\mathrm{t}$ path. This provides further arguments for discrimination between the one- and two-orogenic-cycle concepts of the Variscan evolution in the French Massif Central.

\section{Geological setting and sampling sites}

The five principal nappes in the French Massif Central can be distinguished as follows:

The uppermost allochthon includes epizonal to lowgrade Cambrian to Devonian formations but also amphibolite-facies series as in the Thiviers-Payzac Unit (Bellot and Roig 2007; Duguet et al. 2007; Melleton et al. 2010). Migmatitic high-grade gneisses with HP and UHP relics and the basal leptyno-amphibolitic complexes in the Upper Gneiss Unit (UGU, unité supérieure des gneiss) were thrusted over anatectic gneisses in the Lower Gneiss Unit (LGU, unité inférieure des gneiss). These nappes overlie the Para-Autochthonous units, which are mainly composed of quartzites, micaschists and scarce Ordovician orthogneisses. No early high-pressure relics are observed in the Para-Autochthonous units, which variably underwent lower and upper amphibolite-facies metamorphism (Ledru et al. 1989, 1994; Quenardel et al. 1991; Santallier et al. 1994; Faure et al. 2005, 2009). The thrusting of the UGU over lower grade units is considered to be responsible for an inverted metamorphic stratigraphy ("inverted metamorphism") which is widespread and typical of several regions in the French Massif Central, such as the Aigurande (Rolin and Quenardel 1980), Marvejols (Briand 1978), Rouergue (Burg et al. 1989), Limousin (Friedrich et al. 1988; Roig and Faure 2000; Bellot and Roig 2007), Haut-Allier (Marchand 1974; Burg 1977; Burg et al. 1984; Schulz et al. 1996) and La Sioule (Faure et al. 1993; Schulz et al. 2001; Schulz 2009).

Among the nappes, the UGU was affected by a Late Silurian HP (or UHP) metamorphic event $\mathrm{D}_{0}$, which has been dated at 430-390 Ma in various parts of the French Massif Central (Paquette 1987; Pin and Peucat 1986; Bouchardon et al. 1989; Lardeaux et al. 2001). In both gneiss units (UGU, LGU), the HP stage was followed by a high-grade metamorphism with migmatization, dated as Middle Devonian (385-380 Ma), with a top-to-SW thrusting event $\mathrm{D}_{1}$ (Duthou et al. 1994; Roig and Faure 2000; Cocherie et al. 2005; Faure et al. 2005). The Late Devonian to Early Carboniferous (360-350 Ma) $\mathrm{D}_{2}$ event in the French Massif Central is characterized by a NW-SE-trending lineation, a top-to-NW ductile shearing with thrusting, and a syntectonic amphibolite-facies to high-grade metamorphism (Roig and Faure 2000; Pin and Paquette 2002; Bellot and Roig 2007; Faure et al. 1997, 2005, 2009). The Visean $D_{3}$ event was a top-to-thesouth ductile shearing, evidence of which is widespread in the southern Massif Central. Coevally, in the northern Massif Central, the $\mathrm{D}_{3}$ event corresponded to the onset of syn-orogenic extension. Subsequent two Late Carboniferous events, $\mathrm{D}_{4}$ and $\mathrm{D}_{5}$, took place under syn- and late orogenic extensional tectonic regimes (Mattauer et al. 1988; Malavieille et al. 1990; Malavieille 1993; Faure et al. 1993, 2002, 2009; Faure 1995).

In the Haut-Allier area (Fig. 1), two major tectonic discontinuities of the Devonian to Lower Carboniferous thrusting stage are marked by HT mylonites. The Haut-Allier thrust divides the overlying UGU from the LGU around the anticline of Massiac-Mercoeur with the Ceroux orthogneiss (Fig. 1b, c). To the south, the highgrade leptyno-amphibolite group of the UGU overlies amphibolite-facies metapelites of the Micaschist Unit (MU) along the Nord-Margeridien thrust (Fig. 1c). In several geological sketch maps, these micaschists are assigned to the LGU (Ledru et al. 1989, 1994; Faure et al. 2009). However, they show different lithology, mineral assemblages and metamorphism in the Massiac-Mercoeur anticline. The micaschists can be regarded as a part of the Para-Autochthonous Unit at the base of the nappe pile (Schulz et al. 1996; Faure et al. 2009). A main foliation $\mathrm{S}_{2}$ of micaschists and gneisses in all Haut-Allier metamorphic units is axial-planar to isoclinal $\mathrm{F}_{2}$ folds. The stretching lineation $\mathrm{L}_{2}$ runs parallel to the $\mathrm{F}_{2}$ and $\mathrm{F}_{3}$ axes in a NW-SE direction. Lineations with a SW-NE trend are restricted to the Ceroux region. Foliation $\mathrm{S}_{2}$ as well as the HT mylonite foliation of the thrusts between the lithotectonic units were deformed by $\mathrm{F}_{3}$ folds. The largescale $\mathrm{F}_{3}$ folds with NW dipping axes are accompanied by a crenulation lineation $\mathrm{L}_{3}$ (Marchand et al. 1985,1989).

Garnet-bearing metapelites belonging to the Micaschist Unit are abundant to the south of the NordMargeridien thrust. The samples from Le Boussillion (LBou2-13, R 1531 000, H 4987 350) and L'Arbre Redon (Arb1-8, R 1528 750, H 4987 500) bear staurolite and sillimanite apart from garnet, plagioclase, mica and quartz. The sample from Chazettes (Cht, R 1534 050, H 4985 450) has staurolite, kyanite and sillimanite. Samples from Lesbinières (Les, R 1534 050, H 4986 050) contain staurolite with kyanite, sillimanite and andalusite, the latter 

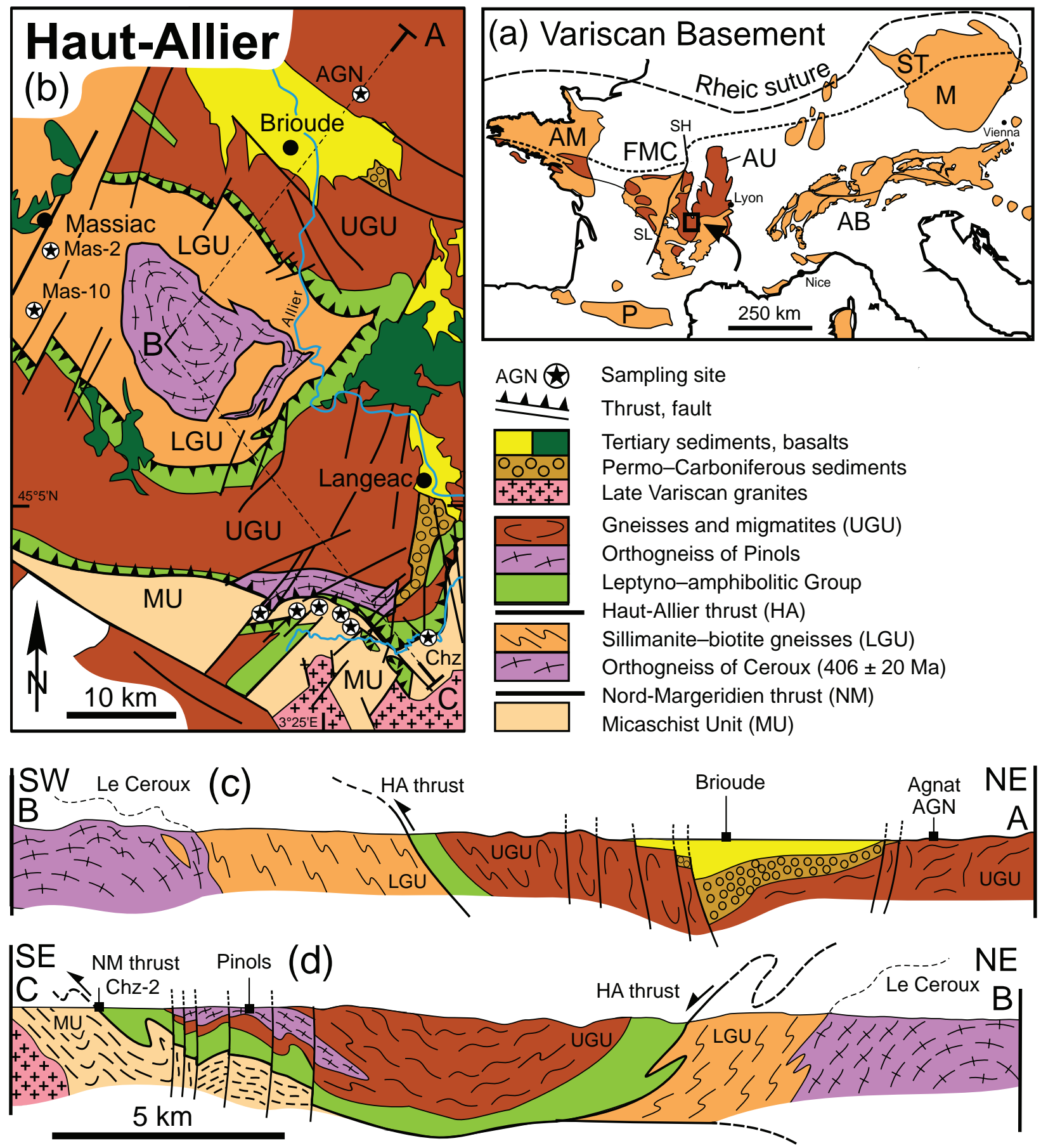

Fig. 1a - Position of the study area within the Variscan basement of Central and Western Europe. AB - Basement of the Alps; AM - Armorican Massif; AU - Allochthonous Units in AM and FMC; FMC - French Massif Central; M - Moldanubian Zone; P - Pyrenees; SH - Sillon Houiller (fault zone); SL - Southern Limousin area; ST - Saxo-Thuringian Zone. b - Geological sketch map with locations of samples and cross sections. c, d - Cross sections of metamorphic sequences in the Haut-Allier region, with sampling locations, adapted from Marchand et al. (1985, 1989). HAHaut-Allier thrust, NM - Nord-Margeridien thrust. LGU - Lower Gneiss Unit, MU - Micaschist Unit (parautochthonous), UGU - Upper Gneiss Unit.

has partially replaced the staurolite. Microstructural and mineral-chemical details, especially the garnet zonation and the $\mathrm{P}-\mathrm{T}$ path reconstructions of the samples from the LGU and MU have been reported in detail in Schulz
(1995) and Schulz et al. (1996). The data reported here refer to the EMP monazite dating of these samples.

The LGU crops out in the Massiac-Mercoeur antiform, below the Haut-Allier thrust (Fig. 1c-d). K-feldspar, sil- 
limanite, biotite and very rare garnet are characteristic phases in the paragneisses. Local leucosomes of partial anatectic melting are observed. The intrusion age of the interlayered orthogneiss of Ceroux in the core of the anticline is at $406 \pm 20 \mathrm{Ma}$ (Bernard-Griffiths et al. 1980). Garnet-bearing sillimanite biotite paragneisses of the LGU were sampled in fresh road cuts in autumn 1991 along the E11-RN9 to the south of Massiac (samples Mas-2, R 1516 250, H 5008 350; Mas-10, R 1514 000, H 5003 250). A HT garnet sillimanite biotite mylonite (sample Chz-2, R 1538 700, H 4985 250) was taken at Chazelles in the Desges river valley (Schulz 1995; Schulz et al. 1996).

The uppermost part of the UGU is mainly made up of anatectic gneisses with sillimanite, cordierite, $\mathrm{K}$-feldspar, and $\mathrm{K}$-feldspar-bearing granulitic kyanite garnet gneisses. Fine-grained grey gneisses, the orthogneiss of Pinols and numerous lenses of eclogites, amphibolites, pyrigarnites and peridotites occur in the leptyno-amphibolitic complex in the basal part of the UGU (Burg 1977; Marchand et al. 1985, 1989). A U-Pb zircon age $(423 \pm 20 \mathrm{Ma})$ from a kyanite-bearing eclogite was interpreted to date a Silurian HP event (Ducrot et al. 1983). A kyanite garnet gneiss horizon of the UGU was sampled in autumn 1991 at two locations along road cuts near the village Agnat. Two samples are from an outcrop next to the village Tridoulon, $1.6 \mathrm{~km}$ SE of Agnat (AGN-1, AGN-6, R 1536 $150, \mathrm{H} 5020$ 250). One specimen is from the location Sarniat (AGN-SAR, R 1534 600, H 5022 250), 1.2 km NW of Agnat. Thin section inspection revealed very similar mineralogy, mode (Tab. 1) and microstructures in all specimens.

\section{Analytical methods}

\subsection{SEM-based automated mineralogy (MLA)}

Automated mineralogical methods (e.g. Fandrich et al. 2007) were applied to complete thin sections of kyanite garnet gneisses and micaschists. The data were acquired

Tab. 1 Mineral modes and grain parameters in kyanite garnet gneisses from Agnat, Upper Gneiss Unit

\begin{tabular}{|c|c|c|c|c|c|c|c|c|c|c|c|c|c|c|c|}
\hline Mode wt. \% XMOD & $\mathrm{rt}-\mathrm{Ca}$ & Grt-Mg & $\mathrm{Bt}$ & Chl & Ms & Qtz & Kfs & $\mathrm{Ab}$ & $\mathrm{Pl}$ & $\mathrm{Ky}$ & Ep & $\mathrm{Fe}-\mathrm{Ti}$ & Ap & Mnz & Zrn \\
\hline AGN-SAR & 4.87 & 10.64 & 13.80 & 0.05 & 0.45 & 31.25 & 14.44 & 3.49 & 13.00 & 5.94 & 0.38 & 0.28 & 0.25 & 0.03 & 0.06 \\
\hline AGN-6 & 05 & .95 & 3.79 & 0.04 & 0.45 & 31.23 & 15.43 & 2.91 & 13.90 & 6.85 & 0.37 & 0.29 & 0.07 & 0.04 & 0.06 \\
\hline AGN-1 & 98 & 31 & 14.32 & 0.30 & 0.52 & 32.61 & 15.24 & 2.09 & 12.70 & 7.45 & 0.34 & .63 & 0.13 & 0.04 & 0.04 \\
\hline Assay wt. \% & $\mathrm{Si}$ & $\mathrm{Ti}$ & $\mathrm{Al}$ & $\mathrm{Fe}$ & $\mathrm{Mn}$ & $\mathrm{Mg}$ & $\mathrm{Ca}$ & $\mathrm{Fe}$ & $\mathrm{Na}$ & $\mathrm{K}$ & $\mathrm{O}$ & $\mathrm{La}$ & $\mathrm{Zr}$ & $P$ & $\mathrm{H}$ \\
\hline AGN-SAR & 29.39 & 0.09 & 9.05 & 5.45 & 0.14 & 1.79 & 1.24 & 5.45 & 1.27 & 3.34 & 47.00 & 0.008 & 0.028 & 0.049 & 0.07 \\
\hline AGN-6 & 29.56 & 0.09 & 9.40 & 5.09 & 0.13 & 1.76 & 1.15 & 5.09 & 1.29 & 3.48 & 47.35 & 0.012 & 0.029 & 0.019 & 0.07 \\
\hline AGN-1 & 29.77 & 0.20 & 9.24 & 5.24 & 0.12 & 1.72 & 1.08 & 5.24 & 1.13 & 3.51 & 47.55 & 0.012 & 0.019 & 029 & 0.08 \\
\hline Mnz V & Grt & $\mathrm{Bt}$ & Qtz & Kfs & $\mathrm{Ab}$ & $\mathrm{Pl}$ & $\mathrm{Ky}$ & Zrn & Grt & $\mathrm{Bt}$ & $\mathrm{Qt}$ & Kfs & $\mathrm{Ab}$ & 1 & Ky \\
\hline AGN-SAR & 10.90 & 23.59 & 30.00 & 8.03 & 0.31 & 4.66 & 14.54 & & 8.36 & 29.86 & 15.64 & 4.35 & 0.54 & 11.26 & 7.60 \\
\hline & & & 3 & & 0 & & 4.23 & & 22 & 22.08 & & 37 & & 7 & .39 \\
\hline AGN-1 & 14 & 28.27 & 38.62 & 8.89 & 2.43 & 3.17 & 5.11 & & 2.97 & 15.99 & 12.21 & 5.47 & 0.18 & 2.56 & 7.53 \\
\hline Retained Grt & 3350 & 2800 & 2400 & 2000 & 1700 & 1400 & 1200 & 1000 & 850 & 710 & 600 & 500 & 425 & 355 & $300 \mu \mathrm{m}$ \\
\hline AGN-SAR & 28.79 & 0.00 & 6.53 & 5.41 & 7.34 & 2.87 & 7.76 & 1.11 & 8.91 & 4.60 & 4.37 & 3.80 & 3.79 & 3.62 & 2.48 \\
\hline AGN-6 & & 9.15 & 0.00 & 0.00 & 0.00 & 8.26 & 7.30 & 6.75 & 8.42 & 3.18 & 3.39 & 2.81 & 1.98 & 1.77 & 0.94 \\
\hline AGN-1 & 41.35 & 0.00 & 0.00 & 4.99 & 6.75 & 6.84 & 8.13 & 3.12 & 3.24 & 3.07 & 3.45 & 4.02 & 3.06 & 2.78 & 1.85 \\
\hline Retain & . & & 125 & 100 & 90 & - & 63 & 53 & 45 & 38 & 32 & 2 & 22 & 19 & $16 \mu \mathrm{m}$ \\
\hline AGN-SAR & 0.00 & & 16.48 & 10.02 & 6.74 & 15.48 & 11.30 & 12.06 & 5.03 & 1.39 & 7.39 & 07 & 2.95 & 1.04 & 0.72 \\
\hline AGN-6 & 12.60 & 18.75 & 0.00 & 4.29 & 10.19 & 9.78 & 8.67 & 10.78 & 7.93 & 4.93 & 4.46 & 1.27 & 1.75 & 1.16 & 1.06 \\
\hline AGN-1 & 0.00 & 0.00 & 0.00 & 0.00 & 25.03 & 11.65 & 25.90 & 9.58 & 7.64 & 3.18 & 5.84 & 2.28 & 3.85 & 1.08 & 0.64 \\
\hline Retained Zrn wt. \% & & & 30 & 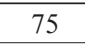 & 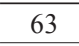 & 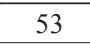 & 45 & 38 & . & 21 & 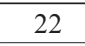 & 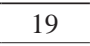 & . & 13.5 & $11.4 \mu \mathrm{m}$ \\
\hline AGN-SAR & 0.00 & 7.56 & 4.26 & 10.71 & 12.74 & 6.41 & 10.39 & 10.87 & 8.04 & 9.65 & 8.19 & 4.29 & 3.27 & 1.33 & 1.29 \\
\hline AGN-6 & 0.00 & 15.89 & 0.00 & 2.45 & 3.68 & 6.82 & 9.74 & 9.10 & 12.37 & 9.82 & 10.74 & 5.98 & 5.65 & 3.49 & 2.37 \\
\hline AGN-1 & 12.54 & 32.92 & 1.55 & 3.37 & 1.54 & 5.02 & 4.73 & 6.08 & 4.86 & 6.23 & 7.05 & 3.90 & 3.82 & 2.46 & 1.83 \\
\hline
\end{tabular}

Recalculated to wt. \%, from automated SEM-EDX mineral liberation analysis (MLA) of thin sections sized $22 \times 40 \mathrm{~mm}$, see text. The XMOD corresponds to point counting with EDX analyses. Chemical assay is calculated with mean mineral compositions, partly from EMP analyses. Locked Mnz and Zrn mean common grain boundaries with adjacent phases according to SPL analysis (see text). Retained wt. \% of garnet, monazite and zircon according to sieve sizes in $\mu \mathrm{m}$; note dominance of a large garnet porphyroblast in each thin section, according to GXMAP analysis (see text). The modes from smaller particle sizes as listed add up to $100 \mathrm{wt}$ \%. Mineral abbreviations after Kretz (1983) apart from Fe-Ti - rutile, ilmenite, hematite; Grt-Ca - Ca-rich garnet; Grt-Mg - Mg-rich garnet. 
by a scanning electron microscope (SEM) Quanta 650-FEG-MLA by FEI Company, equipped with Bruker Dual X-Flash energy dispersive spectrometers for EDX analyses. The electron-beam conditions were set at acceleration voltage of $25 \mathrm{kV}$ at spot 5 which corresponds to a focussed beam with a current of $10 \mathrm{nA}$. The Mineral Liberation Analysis software version MLA 2.9 by FEI Company allows several measurement routines:

1) The XMOD is a single-spot point counting for mineral mode analysis, based on 100,000 EDX spectra collected at a $10 \mu \mathrm{m}$ step in a complete thin section (Tab. 1),

2) The SPL routine combines a backscattered electron (BSE) grey colour value and single-spot EDX-ray spectral analysis for the detection of rare phases such as monazite within their surrounding phases. One receives a catalogue of all monazite intermineral relationships (e.g. Fig. 2c-e), and

3) The GXMAP routine produces a narrow grid of $\sim 1600$ single EDX-ray spectra per $\mathrm{mm}^{2}$ from minerals with defined shades of grey in the backscattered electron (BSE) image. Garnet and biotite were chosen as the target phases (Schulz et al. 2012).

For the classification of mineral phases and mineral compositions in XMOD, SPL and GXMAP measurements, a list of identified reference EDX-ray spectra was applied. This list was established by collecting spectra from matrix phases and along profiles in several zoned garnet porphyroblasts. These garnet reference spectra were also characterized by EDX-ray single-spot elemental analyses which revealed strong variations of $\mathrm{Fe}, \mathrm{Mg}$, $\mathrm{Mn}$ and Ca. In the next step, the reference spectra were labelled with the corresponding garnet $\mathrm{Fe}-\mathrm{Mg}-\mathrm{Mn}-\mathrm{Ca}$ compositions. When the labelled spectra are arranged in a pretty colour scale, they correspond to semi-quantitative garnet zoning maps (Fig. 2a-b). The GXMAP and SPL measurements allowed to select a few typical garnets out of dozens of porphyroblasts and to evaluate monazite grains for CHIME dating by quantitative WDS analysis with electron microprobe (EMP).

\subsection{Electron microprobe (EMP)}

The mineral-chemical data from the samples listed above have been reported in detail in Schulz (1995) and Schulz et al. (1996). The 900 analytical points on garnet, mica and feldspar from the previous study were complemented by further 600 microprobe analyses, enclosing more detailed garnet zonation traverses in the samples from Agnat in the UGU. The measurements on the silicate phases were performed with a JEOL JXA-8900-RL instrument at Institut für Werkstoffwissenschaften, TU Bergakademie Freiberg/Saxony at beam conditions of $15 \mathrm{kV}, 20 \mathrm{nA}, 2 \mu \mathrm{m}$, and with the corresponding ZAF correction procedures.

\subsection{Laser Ablation-ICPMS}

Trace-element analyses of garnet were carried out by a LA-ICPMS hosted at the former Institut für Mineralogie und Kristallstrukturlehre, University of Würzburg (Brätz and Klemd 2002). The instrument was a single collector quadrupole AGILENT 7500i ICP-MS equipped with a $266 \mathrm{~nm}$ Merchantek LUV 266x laser. Argon was used as the carrier gas. The laser was adjusted to an energy of $0.25 \mathrm{~mJ}$ and a repetition rate of $10 \mathrm{~Hz}$. Garnet profiles included 5-10 single shot craters with a diameter of 35 $\mu \mathrm{m}$; the data were compared to the glass reference material standards NIST SRM 612 and SRM 614 (Jackson et al. 1992; Pearce et al. 1997). Silica of garnet rims known from electron microprobe analysis was used as the internal standard; an in-house standard garnet K23 allowed verification of the data. After signal quantification by the GLITTER 3.0 software, On-line Interactive Data Reduction for LA-ICP-MS Program of the year 2000 by Macquarie Research Ltd. (http://www.es.mq.edu.au/ GEMOC), the $1 \sigma$ errors based on counting statistics from signal and background range around $29 \%(\mathrm{Gd}, 3.2 \pm 1.1$ $\mathrm{ppm})$ and $14 \%(\mathrm{Yb}, 123 \pm 18 \mathrm{ppm})$ depending on the absolute concentrations.

\subsection{Electron microprobe (EMP) monazite dating}

Electron-microprobe monazite $\mathrm{Th}-\mathrm{U}-\mathrm{Pb}$ dating is based on the assumption that concentrations of common $\mathrm{Pb}$ in monazite (LREE, Th) $\mathrm{PO}_{4}$ are negligible when compared to radiogenic $\mathrm{Pb}$ resulting from the $\mathrm{Th}$ and $\mathrm{U}$ decay (Montel et al. 1996; Cocherie et al. 1998; Cocherie and Albarede 2001). Electron-microprobe analysis of the $\mathrm{Th}, \mathrm{U}$ and $\mathrm{Pb}$ concentrations in monazite, at a constant ${ }^{238} \mathrm{U}{ }^{235} \mathrm{U}$, allows for the calculation of a chemical model age (CHIME), albeit typically with a considerable error (Suzuki et al. 1994; Montel et al. 1996 ; Pyle et al. 2005; Jercinovic et al. 2008; Suzuki and Kato 2008; Spear et al. 2009). Analysis of $\mathrm{Th}, \mathrm{U}$ and $\mathrm{Pb}$ for calculation of monazite model ages, as well as of $\mathrm{Ca}, \mathrm{Si}$, LREE and $\mathrm{Y}$ for corrections and evaluation of the mineral chemistry, were carried out on a JEOL JXA-8200 at Chair of Applied Mineralogy, University of Erlangen-Nuremberg. The $\mathrm{M}_{\alpha 1}$ lines of $\mathrm{Th}$ and $\mathrm{Pb}$ and the $\mathrm{M}_{\beta 1}$ lines for $\mathrm{U}$ of a PETH crystal were selected for analysis. The analytical conditions were $20 \mathrm{kV}$ acceleration voltage, $100 \mathrm{nA}$ beam current and $5 \mu \mathrm{m}$ beam diameter. The counting times were $320 \mathrm{~s}(\mathrm{~Pb}), 80 \mathrm{~s}(\mathrm{U})$ and $40 \mathrm{~s}(\mathrm{Th})$ on peak. For $\mathrm{Pb}$, the $2 \sigma$ errors ranged typically from 0.016 to $0.024 \mathrm{wt}$. $\%$ for the given dwell time, based on measurement of a reference monazite. The lines $\mathrm{L}_{\alpha 1}$ for La, Y, Ce; $\mathrm{L}_{\beta 1}$ for $\mathrm{Pr}, \mathrm{Sm}, \mathrm{Nd}, \mathrm{Gd}$ and $\mathrm{K}_{\alpha 1}$ for P, Si and Ca were chosen. Orthophosphates of the Smithsonian Institution were used 

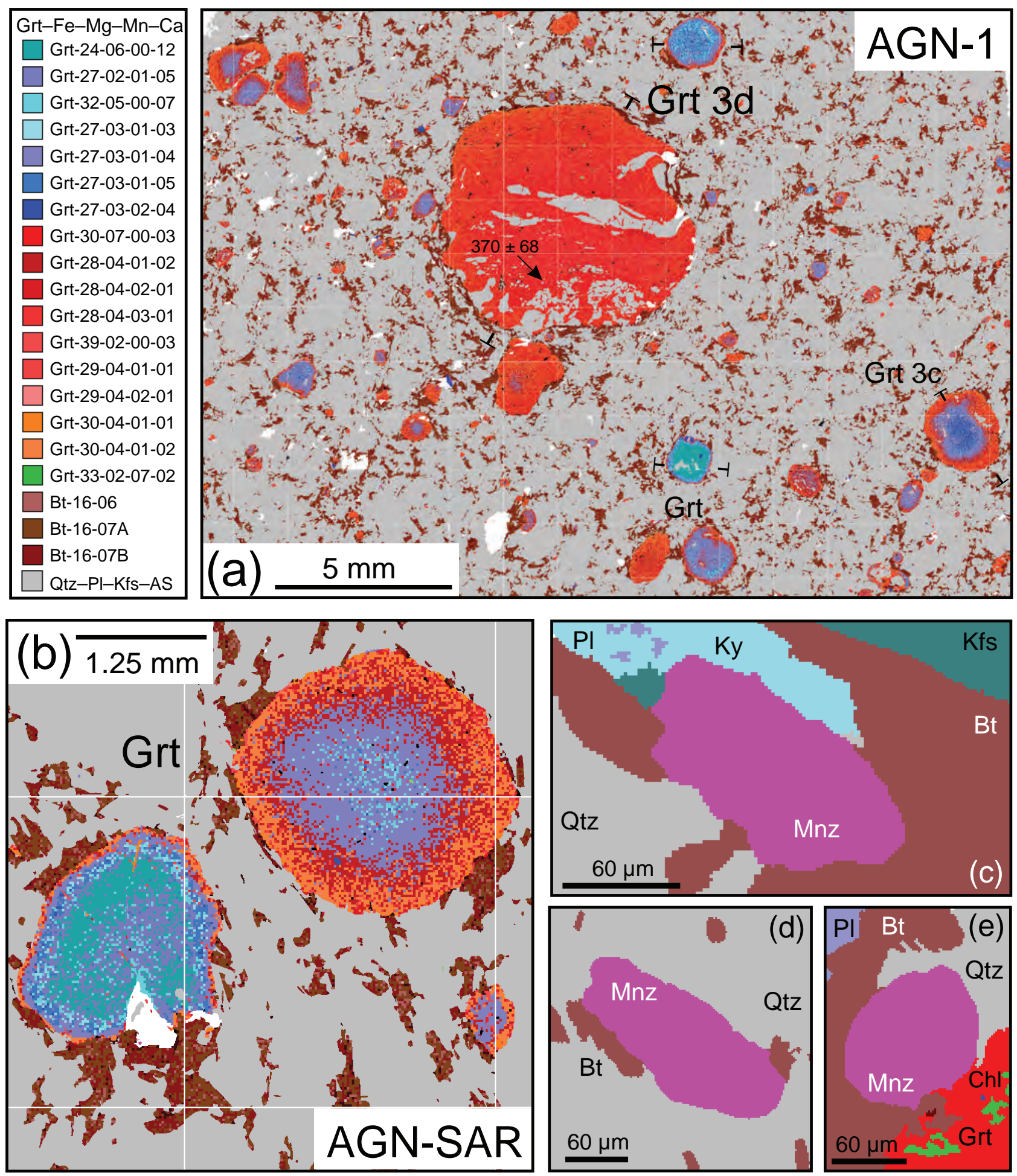

Kfs

Bt

Fig. 2a - Map of energy-dispersive X-ray (EDX) spectra of a polished thin section of kyanite garnet gneiss (location Agnat), produced by GXMAP routine of SEM equipped with MLA 2.9 (see text). The EDX spectra for garnet are labelled by Fe-Mg-Mn-Ca contents in normalized element wt. \% and by colours (blue are Ca-rich, red are Mg-rich compositions). The EDX spectra from biotite are in Fe-Mg (in normalized element wt. \%) and in brown colours. Other minerals are shown in gray colours. Abbreviations of mineral names are after Kretz (1983) apart from AS - aluminium silicate (kyanite). Locations of analytical profiles are marked. b - The EDX spectral map of small garnets in sample AGN-SAR. Note that different widths of Mg-rich zone may indicate partial resorption of Ca-rich cores. $\mathbf{c}-\mathbf{e}$ - Presentation of monazite (Mnz) in microstructures with associated phases in SPL routine of SEM equipped with MLA 2.9 (see text). 
as standards for REE analysis (Jarosewich and Boatner 1991; Donovan et al. 2003). Calibration of $\mathrm{PbO}$ was carried out on a vanadinite standard. The $U$ was calibrated on an appropriate glass standard with $5 \mathrm{wt}$. \% UO. A reference monazite labelled as Madmon, with homogeneous high $\mathrm{ThO}_{2}$ contents, was dated by SHRIMP at $496 \pm 9 \mathrm{Ma}$ and with EMP monazite dating routines established at facilities in Salzburg and BRGM Orléans at $503 \pm 6 \mathrm{Ma}$ (Finger and Helmy 1998; Cocherie et al. 1998; Schulz et al. 2007; Schulz and Schüssler 2013). The Madmon was used for calibration and offline re-calibration of $\mathrm{ThO}_{2}$ as well as for checking the data. Interference of $\mathrm{YL}_{\gamma}$ on the $\mathrm{PbM}_{\alpha}$ line was compensated by linear extrapolation as proposed by Montel et al. (1996). An interference of $\mathrm{ThM}_{\gamma}$ on $\mathrm{UM}_{\beta}$ was also corrected for by using a Th glass standard. The number of single analyses varied with the grain size of the monazites, e.g. 1-2 analyses in grains of $<40 \mu \mathrm{m}$ and up to ten analyses in grains of $100 \mu \mathrm{m}$ in diameter. The monazite chemical ages were determined by two approaches. First, for each single analysis, an age was calculated using the methods of Montel et al. (1996). The error resulting from counting statistics was typically on the order of \pm 20 to $40 \mathrm{Ma}(1 \sigma)$ for Palaeozoic ages. Weighted average ages for monazite populations in the samples were then calculated using Isoplot 3.0 (Ludwig 2001) and are interpreted as the time of closure for the $\mathrm{Th}-\mathrm{U}-\mathrm{Pb}$ system of monazite during growth or recrystallization in course of metamorphism. Second, the ages were determined using the $\mathrm{ThO}_{2}{ }^{*}-\mathrm{PbO}$ isochron method (CHIME) of Suzuki et al. (1994) and Montel et al. (1996), whereby $\mathrm{ThO}_{2} *$ is the sum of the measured $\mathrm{ThO}_{2}$ plus $\mathrm{ThO}_{2}$ equivalent to the $\mathrm{UO}_{2}$. The age was calculated from the slope of the regression line in $\mathrm{ThO}_{2}{ }^{*}$ vs. $\mathrm{PbO}$ coordinates forced through zero. In all analysed samples, the model ages obtained by the two different methods agree exceptionally well.

\section{Mineral chemistry and geothermo- barometry}

In the kyanite garnet gneiss samples from the location Agnat in the Upper Gneiss Unit, biotite and kyanite define a weakly developed foliation $\mathrm{S}_{2}$ in a granoblastic matrix composed of plagioclase, $\mathrm{K}$-feldspar, quartz and garnet (Fig. 2a-b). Mineral modes in wt. \% obtained by the automated XMOD routine with a SEM (reported above) and calculated assay from these mineral modes by involving mean mineral compositions are very similar in the three thin sections (Tab. 1). Plagioclase in the matrix is locally mantled by K-feldspar. Each thin section contains a large garnet porphyroblast which is accompanied by numerous smaller garnets, less than $1.5 \mathrm{~mm}$ across (Tab. 1, Fig. 2a-b). The large garnets in samples AGN-
SAR and AGN-1 display only slightly curved inclusion trails (Fig. 2a). In contrast, the large garnet in sample AGN-6 shows strongly curved S-shaped inclusion trails of kyanite, plagioclase, K-feldspar, biotite, quartz and opaques in the core (labelled as $\mathrm{S}_{1} \mathrm{i}$ ), and a double pressure shadow (or strain shadow) spiral (pss). The strongly curved $\mathrm{S}_{1} \mathrm{i}$ cuts across the pressure shadow double spiral. Such microstructures have been ascribed to a syn-tectonic crystallization of garnet, and more likely and precise, to porphyroblast rotation during crystallization (syncrystalline rotation, Schoneveld 1977; Passchier and Trouw 2005). The assemblage during garnet crystallization was garnet, biotite, plagioclase, K-feldspar, quartz and kyanite. Fibrolitic sillimanite is rare and muscovite is almost absent.

Surprisingly each of the large garnets displays different core-to-rim zonation trends. The sample AGN-SAR is characterized by a rimward decrease in Grs (grossular) and Sps (spessartine), while $\operatorname{Prp}$ (pyrope) increases (Fig. 3a; abbreviation of mineral names according to Kretz 1983). In contrast, the syntectonic garnet AGN-6 is poorly zoned with a slight decrease of Grs and Prp at low Sps contents (Fig. 3b). The large garnet in sample AGN-1 is also weakly zoned (Fig. 3d). The GXMAP semiquantitative garnet compositional maps give evidence that many of the small garnets display a strong zonation with cores high in Grs and Sps (Fig. 2a-b). These core compositions match that of the core of the large garnet AGN-SAR (Fig. 3a, c). The rims of the small garnets display strongly decreasing Grs at increasing $\operatorname{Prp}$ contents. These rim zones have very variable widths even in neighbouring porphyroblasts (Fig. $2 \mathrm{a}-\mathrm{b})$. The modes of Ca-rich and Mg-rich garnet zones are quite similar in the three thin sections (Tab. 1).

From the appearance in the GXMAP spectral maps (Fig. 2a-b), the zonation profiles (Fig. 3a, c) and BSE images it cannot be excluded that some Grs-rich garnet core zones were consumed along their rims or underwent resorption prior to the overgrowth by the Mg-rich zones. Corresponding sharp steps of $\mathrm{Mn}$ and $\mathrm{Ca}$ in the zonation profiles (e. g. Spear 1993) are not obvious, but could be masked by the strongly decreasing Grs contents toward the rims, especially in the small garnets (Fig. 2b). From the zonation profiles and ternary composition plots there are no hints that two distinct generations of garnet crystallised, as it has been described from Variscan polymetamorphic terranes (e. g. Gaidies et al. 2008; Schulz and von Raumer 2011). As some of the large garnets display poor zoning, the question of a HT homogenisation of compositional profiles by diffusion may arise. Such a HT homogenisation would have severely affected the small garnet porphyroblasts. But these are still strongly zoned with well-preserved Mn-rich cores (Fig. 3c).

It can be expected that the cores of large garnet porphyroblasts have recorded an early stage of crystalliza- 


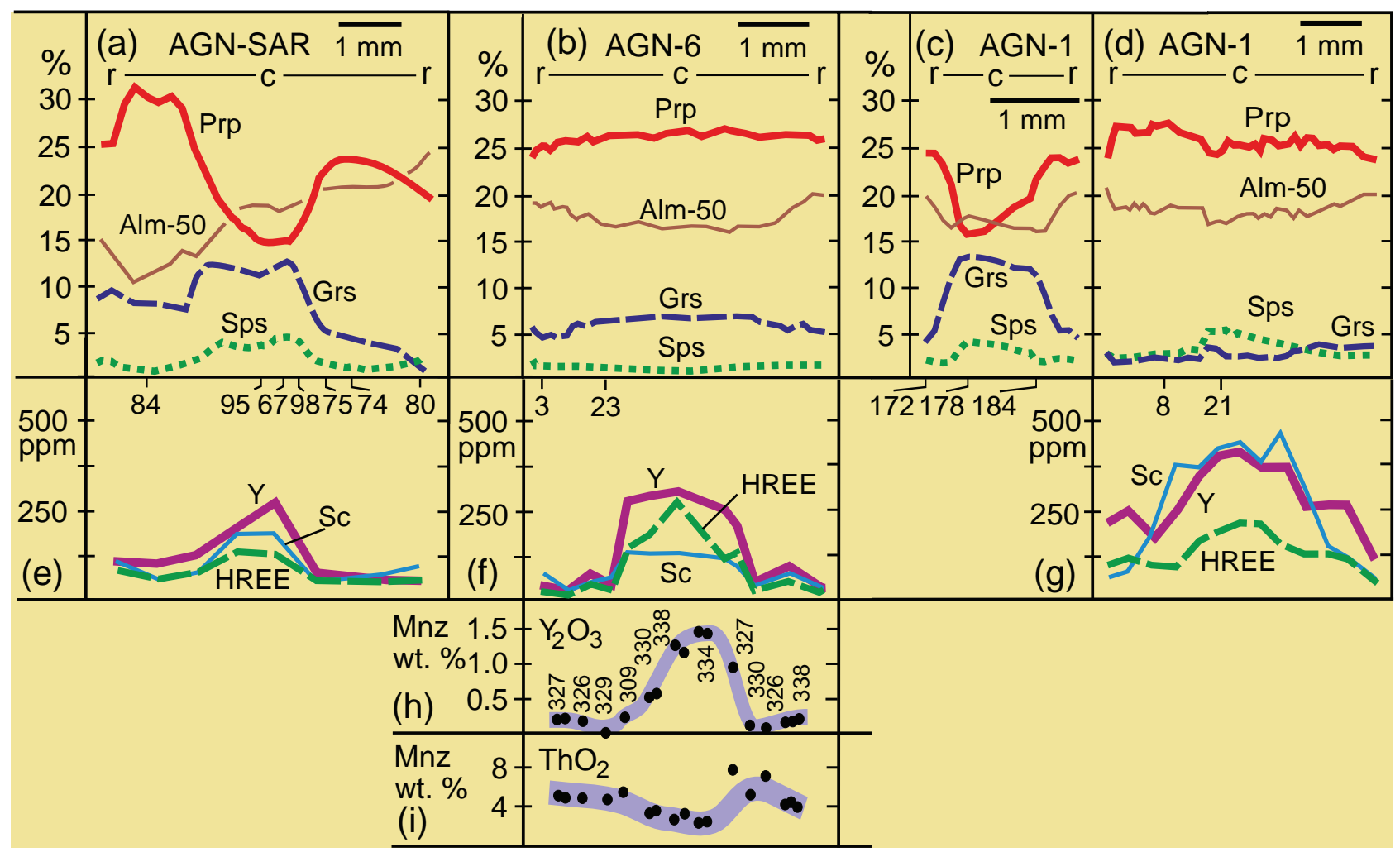

Fig. 3a-d - Zoning of three large and one small garnet grain in almandine (Alm-50\%, due to scale), pyrope (Prp), grossular (Grs) and spessartine (Sps) components (in \%). Data from sample AGN-SAR are in part from Schulz et al. (1996). Numbers mark garnet analyses selected for geothermobarometry. e-g - Trace-element (sum of HREE, Y and Sc) profiles across large garnets (see text). $\mathbf{h}-\mathbf{i}-$ Ages (in $\mathrm{Ma}_{\text {), }} \mathrm{Y}_{2} \mathrm{O}_{3}$ and ThO ${ }_{2}$ contents of small monazite inclusions in syntectonic garnet (Fig. 7a). The monazite inclusions are projected along the rim-core-rim analytical section.

tion. This should be also obvious from corresponding high Sps contents (observed especially in the sample AGN-SAR), as the Mn component is controlled by Rayleigh fractionation (Spear 1993). Data from compositional profiles across both small and large garnets have been plotted in the Prp-Grs-Sps ternary diagrams (Fig. $4 \mathrm{a}-\mathrm{c})$. For the samples AGN-6 and AGN-1, the data from the small grains complement those from the large garnets, forming an evolutionary trend which is very similar to the sample AGN-SAR. From this compilation it is also clear that the Mg-rich rims, as well as the Mg-rich, poorly zoned large garnet porphyroblasts represent a late stage of the garnet chemical evolution.

The trace-element profiles across the three large garnet porphyroblasts display high Y, HREE and Sc contents in the cores and low contents in the rims (Fig. 3e-g). Apparently, for the individual porphyroblasts, they also follow a Rayleigh-type fractionation during garnet growth. Some minor variations in the trace elements in garnet rims could be explained by unintended analysis of small inclusions. The high-Ca and low-Mg early garnet core in sample AGN-SAR has the lowest trace-element contents among the three large porphyroblasts. In contrast, the low-Ca and high-Mg core of the late garnet in sample AGN-1 has the highest trace-element contents in its core.
The large garnet from sample AGN-6 takes an intermediate position among the trace-element core compositions. From GXMAPs and related mode analysis (Tab. 1) and major-element garnet zonation profiles it is known that in each sample the complete garnet chemical evolution which started with high-Ca and low-Mg cores occurred.

Thus, if only Rayleigh-type fractionation ruled the distribution of the trace elements, the late low-Ca high$\mathrm{Mg}$ rich garnets should have lower trace-element contents than the high-Ca low-Mg early cores. This is clearly not the case. One can state that the successively high-to-low Ca contents in the cores of the large garnets correlate with low-to-high Y (Tab. 2). In contrast, for the low-tohigh $\mathrm{Mg}$ contents in the large garnet cores, a positive correlation with increasing Y and HREE can be seen. In consequence, the absolute initial $\mathrm{Y}$ and also HREE abundances in garnet cores appear to have been controlled by the corresponding $\mathrm{Ca}$ and $\mathrm{Mg}$. This implies a dependence on metamorphic pressure and, especially, temperature, additional to a Rayleigh-type fractionation, as has been outlined by Foster et al. (2000) and Pyle et al. (2001) and implemented in geothermometers.

Distinct single garnet analyses which define the general mineral-chemical evolution trends in Fig. 4a-c were selected out of the single core-rim zonation profiles (Figs 

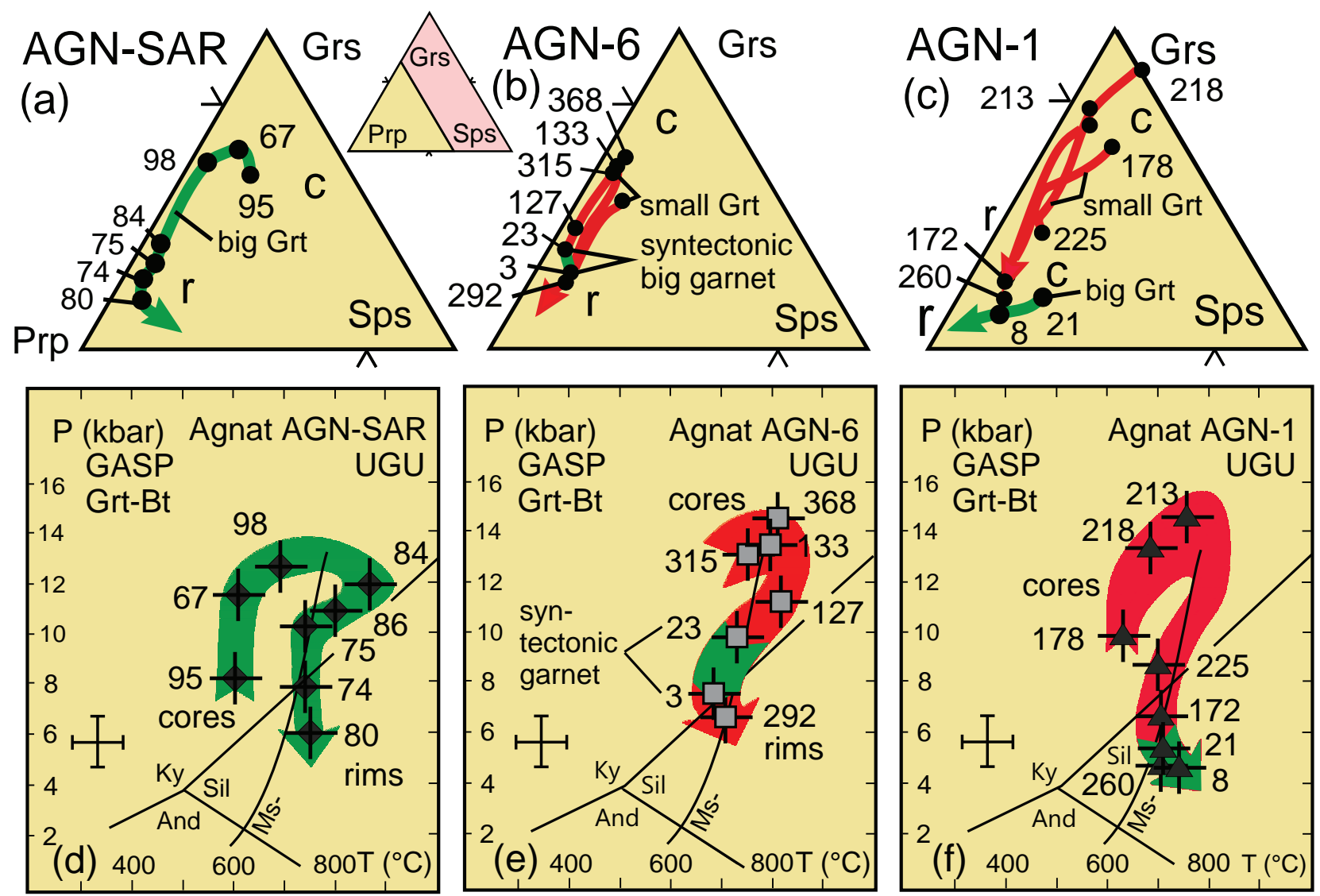

Fig. 4a-c - Garnet compositions in kyanite garnet gneisses from Agnat, in Prp-Grs-Sps (\%) ternary plots. Zonations of large garnets are marked. Arrows indicate core-to-rim (c, r) zonation trends compiled from several single garnet profiles in each sample. Numbers are garnet analyses selected for geothermobarometry from compositional profiles in Fig. 3. d-f - P-T data and P-T paths from Agnat kyanite garnet gneisses, Upper Gneiss Unit. Numbers on $\mathrm{P}-\mathrm{T}$ data refer to garnet analyses in a-c and in Fig. 3. Bold crosses mark results and uncertainty of $\pm 50{ }^{\circ} \mathrm{C} / 1.0 \mathrm{kbar}$ for a combination of a garnet-biotite geothermometer (Grt-Bt) and the garnet-aluminosilicate-plagioclase-quartz geobarometer (GASP). For defined mineral pairs, see Tabs 2 and 3. P-T path sections from large garnets are in green. Aluminosilicate and muscovite-out univariant lines are after Spear (1993).

2a, 3a-d, 4a-c, 7a) and used for geothermobarometry. Biotite enclosed in garnet is considered to be early; biotite along $\mathrm{S}_{2}$ or in pressure shadows around garnet should have crystallised at a later stage. Similarly, early stages of mineral chemical evolution are given by plagioclase enclosed in garnets, or the cores of zoned plagioclase porphyroblasts. The late-stage crystallization is documented from plagioclase aligned along $\mathrm{S}_{2}$ or in the rims of zoned porphyroblasts. The early biotites which can be related to the Mg-poor and Mn-rich garnet cores have $X_{\mathrm{Mg}}$ between 0.56 and 0.53 and are slightly different in each sample. The $X_{\mathrm{Mg}}$ in biotite slightly decrease with the increase of $\mathrm{Mg}$ in garnet (Tab. 3). In plagioclase of sample AGN-SAR one observes first decreasing $\mathrm{Ca}$ contents $\left(\mathrm{An}_{24-16}\right)$, then rising again $\left(\mathrm{An}_{22-28}\right)$. In samples AGN-6 and AGN-1, these variations between the plagioclases enclosed in garnet cores and in zoned matrix porphyroblasts are less pronounced (Tab. 3). One can relate the mineral chemical data from biotite and plagioclase to the garnet compositional evolution for the early and late stages of crystallization. This corresponds to criteria for the definition of local equilibria based on microstructural observations and the chemical evolution of the mineral phases (Triboulet and Audren 1985; Schulz 1993; Schulz et al. 2001). Such localised equilibria within low-variance assemblages allow evaluating $\mathrm{P}-\mathrm{T}$ changes for the consecutive stages of garnet growth by geothermobarometry (Spear 1993). Mica and plagioclase of $\mathrm{S}_{1} \mathrm{i}$ in garnets or in inclusions were related to early, and syn-S mica and plagioclase to late stages of garnet growth. Inclusions in different sites (core, intermediate zone, rim) of garnets were assigned to the corresponding parts of the porphyroblasts. Rims of zoned plagioclase, unzoned plagioclase and $\mathrm{S}_{2}$-biotite were correlated to the garnet rims, but excluding the outer parts of the rims with increase in Mn.

Such mineral pairs of garnet-biotite and garnet-plagioclase, as described in Schulz et al. (1996) and presented in Tab. 3, were used for geothermobarometry. The $\mathrm{P}-\mathrm{T}$ conditions for crystallization of garnets have been calculated using the garnet-biotite thermometer of Bhattacharya et al. (1992) in combination with the linearized calibrations of the garnet-aluminosilicate-plagioclase- 
Tab. 2 Electron microprobe and LA-ICPMS analyses of garnet in kyanite garnet gneisses from Agnat, Upper Gneiss Unit

\begin{tabular}{|c|c|c|c|c|c|c|c|c|c|c|c|c|c|c|c|}
\hline \multirow{3}{*}{$\begin{array}{l}\text { Grt } \\
\text { (wt. \%) }\end{array}$} & \multicolumn{5}{|c|}{ AGN-SAR } & \multicolumn{5}{|c|}{ AGN-6 } & \multicolumn{5}{|c|}{ AGN-1 } \\
\hline & cores & & & & rims & cores & & & & rims & cores & & & & rims \\
\hline & $95-b c$ & 67 & 98 & 84 & 80-br & 368 & 133 & 127 & $23-b c$ & 3-br & 218 & 225 & 260 & $21-b c$ & 8-br \\
\hline $\mathrm{SiO}_{2}$ & 38.51 & 37.07 & 38.54 & 38.98 & 38.48 & 38.85 & 38.70 & 38.19 & 37.93 & 37.91 & 38.37 & 38.67 & 38.13 & 38.07 & 37.81 \\
\hline $\mathrm{Al}_{2} \mathrm{O}_{3}$ & 21.88 & 21.34 & 21.74 & 22.13 & 22.21 & 20.95 & 21.78 & 21.58 & 21.55 & 21.65 & 20.85 & 20.69 & 20.87 & 21.48 & 21.47 \\
\hline $\mathrm{FeO}$ & 32.53 & 30.48 & 30.98 & 28.82 & 32.91 & 27.49 & 27.44 & 28.94 & 30.59 & 31.96 & 26.18 & 31.56 & 32.87 & 31.27 & 32.01 \\
\hline $\mathrm{MnO}$ & 1.17 & 1.95 & 0.38 & 0.35 & 0.87 & 0.71 & 0.74 & 0.77 & 0.37 & 0.82 & 1.90 & 1.14 & 1.00 & 2.27 & 1.09 \\
\hline $\mathrm{MgO}$ & 3.67 & 3.67 & 4.77 & 8.14 & 5.98 & 6.49 & 6.53 & 7.17 & 6.81 & 6.08 & 3.83 & 5.50 & 5.64 & 6.56 & 6.96 \\
\hline $\mathrm{CaO}$ & 4.04 & 4.35 & 4.55 & 2.93 & 1.33 & 4.97 & 5.23 & 2.86 & 2.37 & 1.89 & 8.62 & 2.58 & 0.96 & 0.91 & 0.75 \\
\hline Sum & 101.80 & 98.86 & 100.96 & 101.35 & 101.78 & 99.44 & 100.42 & 99.50 & 99.63 & 100.31 & 99.74 & 100.13 & 99.46 & 100.56 & 100.09 \\
\hline$\overline{\mathrm{Si}}$ & 3.004 & 2.982 & 3.007 & 2.982 & 2.982 & 3.038 & 2.998 & 2.992 & 2.983 & 2.979 & 3.025 & 3.047 & 3.030 & 2.986 & 2.976 \\
\hline $\mathrm{Al}$ & 2.012 & 2.007 & 2.000 & 1.995 & 2.012 & 1.931 & 1.989 & 1.993 & 1.998 & 2.005 & 1.937 & 1.921 & 1.954 & 1.985 & 1.991 \\
\hline $\mathrm{Fe}$ & 2.122 & 2.051 & 2.022 & 1.844 & 2.133 & 1.798 & 1.778 & 1.897 & 2.012 & 2.100 & 1.726 & 2.079 & 2.184 & 2.051 & 2.107 \\
\hline $\mathrm{Mn}$ & 0.077 & 0.133 & 0.025 & 0.023 & 0.057 & 0.047 & 0.049 & 0.051 & 0.025 & 0.055 & 0.127 & 0.076 & 0.068 & 0.151 & 0.073 \\
\hline Mg & 0.427 & 0.435 & 0.555 & 0.928 & 0.691 & 0.756 & 0.755 & 0.837 & 0.798 & 0.712 & 0.450 & 0.646 & 0.668 & 0.767 & 0.816 \\
\hline $\mathrm{Ca}$ & 0.338 & 0.375 & 0.380 & 0.240 & 0.110 & 0.416 & 0.434 & 0.240 & 0.200 & 0.159 & 0.729 & 0.218 & 0.082 & 0.076 & 0.063 \\
\hline Prp & 14.4 & 14.5 & 18.6 & 31.1 & 23.1 & 25.1 & 25.2 & 28.0 & 26.8 & 23.9 & 14.9 & 21.4 & 22.2 & 25.7 & 27.5 \\
\hline Sps & 2.6 & 4.4 & 0.8 & 0.8 & 1.9 & 1.6 & 1.6 & 1.7 & 0.8 & 1.8 & 4.2 & 2.5 & 2.3 & 5.1 & 2.5 \\
\hline Grs & 11.4 & 12.5 & 12.7 & 8.1 & 3.7 & 13.8 & 14.5 & 8.0 & 6.7 & 5.3 & 24.0 & 7.2 & 2.7 & 2.6 & 2.1 \\
\hline Alm & 71.6 & 68.5 & 67.8 & 60.1 & 71.3 & 59.6 & 58.7 & 62.3 & 65.7 & 69.0 & 56.9 & 68.9 & 72.8 & 66.7 & 67.9 \\
\hline$\overline{(p p m)}$ & $5-c$ & 4 & 3 & 6 & 1 & 7-c & 6 & 10 & 4 & 2 & 7-c & 6 & 4 & 2 & 13 \\
\hline $\mathrm{Li}$ & 3.4 & 3.4 & 2.9 & 3.8 & 4.2 & 13.0 & 9.2 & 6.1 & 59.7 & 76.6 & 41.8 & 50.6 & 33.4 & 50.1 & 75.8 \\
\hline Sc & 180.0 & 184.0 & 76.0 & 96.4 & 98.1 & 136.0 & 129.0 & 95.5 & 37.4 & 36.8 & 443.0 & 424.0 & 382.0 & 85.9 & 53.6 \\
\hline $\mathrm{Ti}$ & 216.0 & 257.0 & 52.4 & 159.0 & 129.0 & 68.1 & 60.0 & 68.8 & 50.0 & 40.0 & 114.0 & 61.7 & 54.0 & 38.0 & 66.2 \\
\hline V & 42.7 & 35.4 & 30.1 & 32.2 & 18.6 & 59.6 & 34.5 & 25.6 & 29.6 & 28.7 & 35.6 & 32.8 & 39.0 & 27.6 & 29.9 \\
\hline $\mathrm{Cr}$ & 84.1 & 74.5 & 42.4 & 40.5 & 34.6 & 79.0 & 82.4 & 66.2 & 95.0 & 31.2 & 52.5 & 68.4 & 32.5 & 51.3 & 52.1 \\
\hline $\mathrm{Ga}$ & 4.9 & 5.4 & 7.0 & 4.8 & 4.0 & 9.1 & 7.5 & 11.1 & 7.3 & 8.4 & 5.5 & 3.6 & 4.8 & 4.7 & 4.8 \\
\hline $\mathrm{Y}$ & 260.0 & 194.0 & 121.0 & 66.8 & 100.0 & 305.0 & 288.0 & 215.0 & 43.0 & 30.8 & 422.0 & 401.0 & 249.0 & 255.0 & 113.0 \\
\hline $\mathrm{Zr}$ & 3.5 & 2.9 & 2.9 & 4.0 & 3.6 & 2.0 & 2.9 & 2.8 & 3.0 & 2.1 & 1.9 & 1.7 & 1.1 & 1.7 & 2.5 \\
\hline $\mathrm{Gd}$ & 23.3 & 31.0 & 11.0 & 13.5 & 11.0 & 9.1 & 7.3 & 12.5 & 4.5 & 4.4 & 9.9 & 10.0 & 2.3 & 4.1 & 3.7 \\
\hline $\mathrm{Tb}$ & 6.0 & 6.1 & 2.6 & 2.1 & 2.4 & 3.1 & 2.9 & 3.4 & 1.3 & 1.3 & 5.8 & 4.5 & 2.1 & 2.6 & 1.9 \\
\hline Dy & 42.5 & 33.7 & 19.8 & 11.7 & 16.1 & 33.5 & 35.4 & 30.3 & 9.2 & 7.2 & 65.9 & 59.9 & 34.7 & 31.2 & 20.3 \\
\hline Но & 8.2 & 6.8 & 4.1 & 2.5 & 3.3 & 12.9 & 12.2 & 8.5 & 1.7 & 1.0 & 17.7 & 14.5 & 9.7 & 8.7 & 4.0 \\
\hline Er & 21.4 & 20.6 & 10.9 & 7.4 & 11.2 & 57.9 & 44.4 & 34.5 & 4.4 & 3.4 & 53.4 & 49.2 & 26.0 & 31.1 & 10.3 \\
\hline $\mathrm{Tm}$ & 3.1 & 2.9 & 1.8 & 0.9 & 1.7 & 12.7 & 8.6 & 6.7 & 0.3 & 0.4 & 8.2 & 6.2 & 3.4 & 5.0 & 1.7 \\
\hline $\mathrm{Yb}$ & 16.8 & 19.7 & 9.4 & 6.4 & 17.7 & 120.0 & 65.2 & 37.1 & 3.0 & 2.4 & 51.2 & 43.1 & 18.3 & 29.9 & 10.8 \\
\hline $\mathrm{Lu}$ & 2.7 & 2.8 & 1.5 & 1.2 & 3.4 & 24.8 & 8.9 & 5.4 & 0.7 & 0.6 & 7.7 & 6.5 & 2.0 & 5.4 & 1.4 \\
\hline$\sum$ HREE & 123.9 & 123.5 & 61.1 & 45.6 & 66.9 & 274.0 & 184.9 & 138.3 & 25.1 & 20.6 & 219.8 & 193.9 & 98.5 & 117.9 & 54.1 \\
\hline
\end{tabular}

Major-element analyses are arranged for each sample according to the garnet mineral-chemical evolution in Prp-Grs- Sps ternary (Fig. 4a-c); some analyses are from cores and rims of large porphyroblasts (bc, br). Cations are normalised to $12 \mathrm{O}$. Trace-element analyses are from cores to rims of the large porphyroblasts.

quartz (GASP) barometer, based on an internally consistent thermodynamic data set (Holland and Powell 1990), with the activity models for garnet (Ganguly et al. 1996) and plagioclase (Powell and Holland 1993). Tentative calculations by other and updated calibrations (Holdaway 2001; Wu and Cheng 2006) yielded no substantially different results. Pseudosection calculations for garnet core compositions could provide no more reliable constraints on $\mathrm{P}$ and T. In fact, the contouring of divariant fields with garnet $X_{\mathrm{Ca}}$ and $X_{\mathrm{Mg}}$ isolines in pseudosections corresponds to the thermobarometric methods employed here, but also includes the additional assumption and thus uncertainty upon the reactant bulk composition(s) in rock domains of unknown size.
Thermobarometric data from the three Agnat samples reveal an overall clockwise $\mathrm{P}-\mathrm{T}$ path. The individual $\mathrm{P}-\mathrm{T}$ path segments from each single sample do not all overlap, but they can be combined into a prograde-retrograde $\mathrm{P}-\mathrm{T}$ evolution. An early prograde $\mathrm{P}-\mathrm{T}$ development from $600{ }^{\circ} \mathrm{C} / 8 \mathrm{kbar}$ to $700{ }^{\circ} \mathrm{C} / 13 \mathrm{kbars}$ is documented in garnet cores in samples AGN-SAR and AGN-1 (Fig. 4d, f). Maximal pressures were followed by maximal temperatures at $800^{\circ} \mathrm{C} / 11$ kbar. A segment of nearly isothermal decompression from $10-5 \mathrm{kbar}$ at $700-750^{\circ} \mathrm{C}$ is obvious in all three samples. The formation of the syncrystalline-rotated garnet in sample AGN-6 occurred at this stage (Fig. 4b, e). In sample AGN-1, the poorly zoned large garnet recorded a final increase of tempera- 
Early Carboniferous $P-T-t$ path from Haut-Allier, French Massif Central

Tab. 3 Electron-microprobe analyses of biotite and plagioclase in kyanite garnet gneisses from Agnat, Upper Gneiss Unit

\begin{tabular}{|c|c|c|c|c|c|c|c|c|c|c|c|c|c|c|c|}
\hline \multirow[b]{2}{*}{$\mathrm{Bt}$} & \multicolumn{5}{|c|}{ AGN-SAR } & \multicolumn{5}{|c|}{ AGN-6 } & \multicolumn{5}{|c|}{ AGN-1 } \\
\hline & 140 & 83 & 147 & 92 & 95 & 307 & 102 & 82 & 84 & 100 & 207 & 240 & 78 & 77 & 69 \\
\hline $\mathrm{Si}$ & 5.399 & 5.194 & 5.412 & 5.313 & 5.328 & 5.382 & 5.358 & 5.209 & 5.377 & 5.349 & 5.341 & 5.352 & 5.417 & 5.393 & 5.378 \\
\hline $\mathrm{Ti}$ & 0.479 & 0.370 & 0.571 & 0.542 & 0.602 & 0.670 & 0.449 & 0.540 & 0.559 & 0.526 & 0.634 & 0.643 & 0.557 & 0.551 & 0.527 \\
\hline $\mathrm{Al}^{\mathrm{IV}}$ & 2.601 & 2.806 & 2.588 & 2.687 & 2.672 & 2.618 & 2.642 & 2.791 & 2.623 & 2.651 & 2.659 & 2.648 & 2.583 & 2.607 & 2.622 \\
\hline $\mathrm{Al}^{\mathrm{VI}}$ & 0.509 & 0.678 & 0.486 & 0.523 & 0.463 & 0.440 & 0.638 & 0.440 & 0.541 & 0.492 & 0.410 & 0.365 & 0.551 & 0.553 & 0.441 \\
\hline $\mathrm{Fe}$ & 2.050 & 2.081 & 2.126 & 2.289 & 2.291 & 2.041 & 2.073 & 2.312 & 2.004 & 2.061 & 2.090 & 2.141 & 2.135 & 2.119 & 2.136 \\
\hline Mn & 0.002 & 0.009 & 0.002 & 0.012 & 0.019 & 0.008 & 0.001 & 0.004 & 0.003 & 0.006 & 0.003 & 0.003 & 0.001 & 0.000 & 0.005 \\
\hline $\mathrm{Mg}$ & 2.590 & 2.612 & 2.380 & 2.221 & 2.179 & 2.311 & 2.470 & 2.459 & 2.467 & 2.544 & 2.407 & 2.422 & 2.312 & 2.119 & 2.510 \\
\hline $\mathrm{Na}$ & 0.073 & 0.051 & 0.043 & 0.059 & 0.042 & 0.068 & 0.038 & 0.040 & 0.028 & 0.066 & 0.033 & 0.028 & 0.029 & 0.037 & 0.041 \\
\hline K & 1.778 & 1.836 & 1.768 & 1.849 & 1.854 & 1.823 & 1.780 & 1.677 & 1.779 & 1.768 & 1.855 & 1.814 & 1.763 & 1.795 & 1.826 \\
\hline Sum & 15.48 & 15.64 & 15.38 & 15.50 & 15.45 & 15.36 & 15.46 & 15.49 & 15.38 & 15.46 & 15.43 & 15.42 & 15.35 & 15.17 & 15.49 \\
\hline $\mathrm{X}_{\mathrm{Mg}}$ & 0.56 & 0.56 & 0.53 & 0.49 & 0.49 & 0.53 & 0.54 & 0.52 & 0.55 & 0.55 & 0.54 & 0.53 & 0.52 & 0.50 & 0.54 \\
\hline $\mathrm{Pl}$ & $118 \mathrm{iGrt}$ & 89 & 88 & & 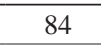 & & 90iGrt & 89iGrt & 190 & & 230iGrt & 204 & 01 & 00 & 54 \\
\hline $\mathrm{Si}$ & 2.838 & 2.727 & 2.778 & 2.827 & 2.707 & 2.822 & 2.720 & 2.754 & 2.882 & 2.795 & 2.782 & 2.770 & 2.830 & 2.848 & 2.869 \\
\hline $\mathrm{Al}$ & 1.160 & 1.318 & 1.220 & 1.176 & 1.296 & 1.160 & 1.313 & 1.245 & 1.124 & & 1.207 & 1.205 & 1.167 & 1.148 & 1.126 \\
\hline $\mathrm{Ca}$ & 0.222 & 0.150 & 0.221 & 0.234 & 0.281 & 0.202 & 0.215 & 0.250 & 0.187 & 0.219 & 0.237 & 0.247 & 0.233 & 0.217 & 0.200 \\
\hline $\mathrm{Na}$ & 0.690 & 0.729 & 0.738 & 0.682 & 0.691 & 0.788 & 0.662 & 0.721 & 0.693 & 0.708 & 0.757 & 0.789 & 0.698 & 0.706 & 0.705 \\
\hline $\mathrm{K}$ & 0.020 & 0.067 & 0.034 & 0.012 & 0.013 & 0.034 & 0.072 & 0.009 & 0.029 & 0.026 & 0.018 & 0.014 & 0.012 & 0.017 & 0.035 \\
\hline Sum & 4.931 & 4.990 & 4.991 & 4.931 & 4.988 & 5.007 & 4.983 & 4.979 & 4.915 & 4.963 & 5.001 & 5.024 & 4.939 & 4.935 & 4.935 \\
\hline An & 23.8 & 15.8 & 22.2 & 25.2 & 28.5 & 19.8 & 22.7 & 25.5 & 20.6 & 23.0 & 23.4 & 23.6 & 24.7 & 23.1 & 21.3 \\
\hline $\mathrm{Ab}$ & 74.0 & 77.1 & 74.4 & 73.5 & 70.1 & 76.9 & 69.7 & 73.6 & 76.2 & 74.3 & 74.8 & 75.1 & 74.0 & 75.1 & 75.0 \\
\hline Kfs & 2.2 & 7.1 & 3.4 & 1.3 & 1.4 & 3.3 & 7.6 & 0.9 & 3.2 & 2.7 & 1.8 & 1.3 & 1.3 & 1.8 & 3.8 \\
\hline
\end{tabular}

Cations are normalised to $11 \mathrm{O}$ and $8 \mathrm{O}$, respectively. The following garnet-biotite-plagioclase pairs were combined for geothermobarometry: Sample AGN-SAR: 95-140-118; 67-83-89; 98-147-89; 84-147-157; 86-140-117; 75-91-88; 74-90-85; 80-95-84. AGN-6: 315-334-298; 133-10289; 368-307-328; 127-82-89; 23-84-198; 3-100-103; 292-337-322. AGN-1: 178-209-230; 218-207-230; 213-207-234; 225-240-204; 172-240-204; $21-69-54 ; 8-78-66$

ture $\left(700-750^{\circ} \mathrm{C}\right)$ at slightly decreasing pressures from 6 to 5 kbar (Fig. 4c, f).

Two assumptions of equilibrium are critical to thermobarometry and also pseudosection calculations: (1) heterogeneous equilibrium was achieved and preserved within a given volume of rock, and (2) Fe-Mg exchange between garnet and biotite as well as Ca net-transfer from garnet to plagioclase ceased equilibrating at the same time.

When these basic assumptions are accepted, uncertainties of $\mathrm{P}-\mathrm{T}$ paths calculated from the zoned minerals arise from quantitative systematic error in electron-microprobe analyses and thermodynamic data. Such errors will not affect the general shapes or relative positions of P-T paths. All geothermobarometric estimates include a minimum error of $\pm 50^{\circ} \mathrm{C}$ and $\pm 1 \mathrm{kbar}$. The dependence of the calculated P-T path on garnets $X_{\mathrm{Ca}}$ and $X_{\mathrm{Mg}}$ evolution is intensified when corresponding micas and plagioclases have only slight compositional variations, or when $X_{\mathrm{Mg}}$ in biotite and $X_{\mathrm{Ca}}$ in plagioclase evolved oppositely to the corresponding $X_{\mathrm{Mg}}$ and $X_{\mathrm{Ca}}$ variations in garnets. Shapes or the relative $\mathrm{P} / \Delta \mathrm{T}$ trends of $\mathrm{P}-\mathrm{T}$ paths appear to be mainly preserved when the uncertainties regarding corresponding plagioclase and biotite are considered (Schulz et al. 2001). Due to the preserved high-Mn cores in small garnet porphyroblasts, a high-temperature homogenisation by cation diffusion with its effects on geothermobarometry (Spear 1993) can be excluded. It has been suggested from thermodynamic modeling of garnet-bearing assemblages with staurolite, muscovite and chlorite that garnet should not crystallise and/or should be resorbed during isothermal uplift and uplift-cooling paths (e. g. Spear et al. 1990; Spear 1993). The same but reduced effect should occur for garnet in an assemblage with kyanite and $\mathrm{K}$-feldspar, lacking muscovite and chlorite, outside of the staurolite stability field (Spear and Pyle 2010). Partial resorption of garnet should result in gaps, breaks and marked steps of the P-T record. Such P-T path segments with potential garnet resorption are exemplified in some parts of the Agnat P-T evolution. At Agnat, one cannot exclude resorption of the Ca- and Mn-rich garnet zones when Ca strongly decreases toward the rims. Such possible artefacts of resorption would be masked at the decompression stage of the $\mathrm{P}-\mathrm{T}$ path. It is also possible that simultaneous resorption and growth of garnet occur at different microstructural sites during heterogeneous deformation. Furthermore, one can state that at least the late large garnet in sample AGN-1 crystallised at increasing temperature and thus should give reliable $\mathrm{P}-\mathrm{T}$ estimates for the end of garnet crystallization. As a consequence, the combined P-T data from the three Agnat samples complete the $\mathrm{P}-\mathrm{T}$ path for the UGU, and set it apart from 

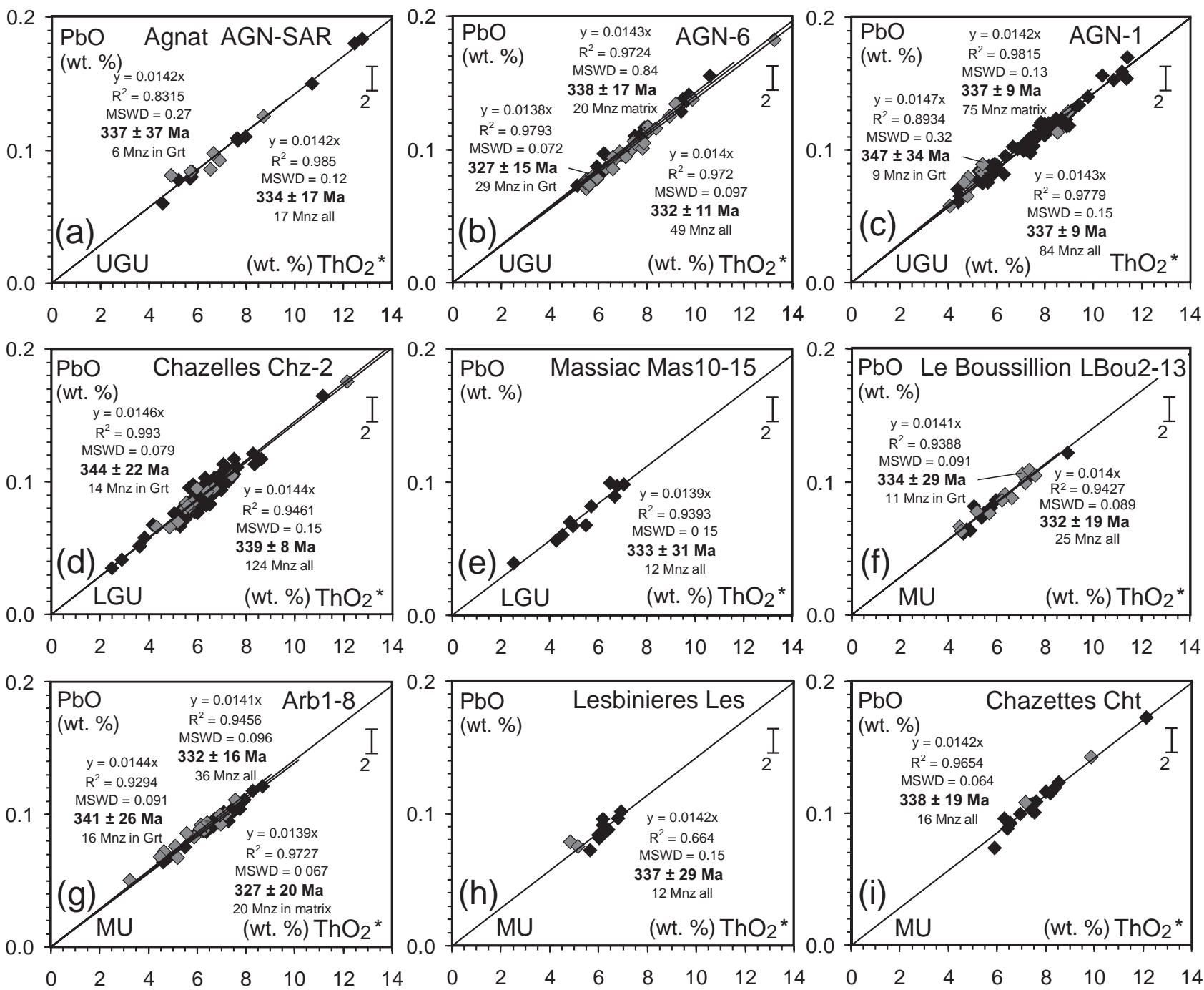

Fig. 5 - Electron-microprobe monazite chemical age data from matrix and grains enclosed in garnet, in $\left.\mathrm{ThO}_{2} *-\mathrm{PbO}_{\left(\mathrm{ThO}_{2}\right.} *=\mathrm{ThO}_{2}+\mathrm{ThO}_{2 \mathrm{EQU}-\mathrm{U}}\right)$ isochron diagrams. Minimal error on monazite $\mathrm{PbO}$ analyses is shown by a bar. Regression lines are forced through zero (Suzuki et al. 1994; Montel et al. 1996). Weighted average ages (Ma) with MSWD and $2 \sigma$ minimal error are calculated from single analyses (Ludwig 2001), whose numbers are also given. For sample locations, see Fig. 1b.

the P-T paths from the LGU and MU already presented in Schulz et al. (1996). In each case, the P-T paths represent the best possible information that can be extracted from growth-zoned garnets and co-existing phases.

\section{Monazite ages and mineral chemistry}

Monazite in the samples from UGU, LGU and MU display variable contents of $\mathrm{ThO}_{2}$ (3-10 wt. \%: Fig. 5, Tab. 4). But in most samples rather constant $\mathrm{ThO}_{2}$ of $\sim 5$ wt. \% are observed, regardless their age. Similar isochrons in $\mathrm{ThO}_{2}{ }^{*}$ vs. $\mathrm{PbO}$ plots were found in the three nappe units. Isochron ages recalculated from all monazites in the UGU range between 332 and 337 Ma (Fig. $5 \mathrm{a}-\mathrm{c})$. In the LGU, represented by the samples from Cha- zelles and Massiac (Fig. 5d-e), the ages range between 333 and 339 Ma. Monazite ages from isochrons in the micaschist samples range from 332 to $338 \mathrm{Ma}$ (Fig. 5f-i). Within the error, the ages of monazites in the matrix and enclosed in garnet overlap; however, the isochrons from the enclosed monazites are slightly older. In the U/Pb vs. $\mathrm{Th} / \mathrm{Pb}$ coordinates, the general trend of monazite data in the UGU does not plot parallel to the $300 \mathrm{Ma}$ isochron (Fig. 6a-c). This is supported by detailed inspection of the monazite age distribution in histograms (Fig. 6d-f). An upper limit of the monazite ages is at $\sim 360 \mathrm{Ma}$ in all three nappe units. Only a few monazites fall in the age group 370-400 Ma. This concerns single but also multiple analyses from single grains (Fig. 7b). The age group between 300 and $320 \mathrm{Ma}$ is also similar in all three units. The distribution of maxima in the dominant age group 


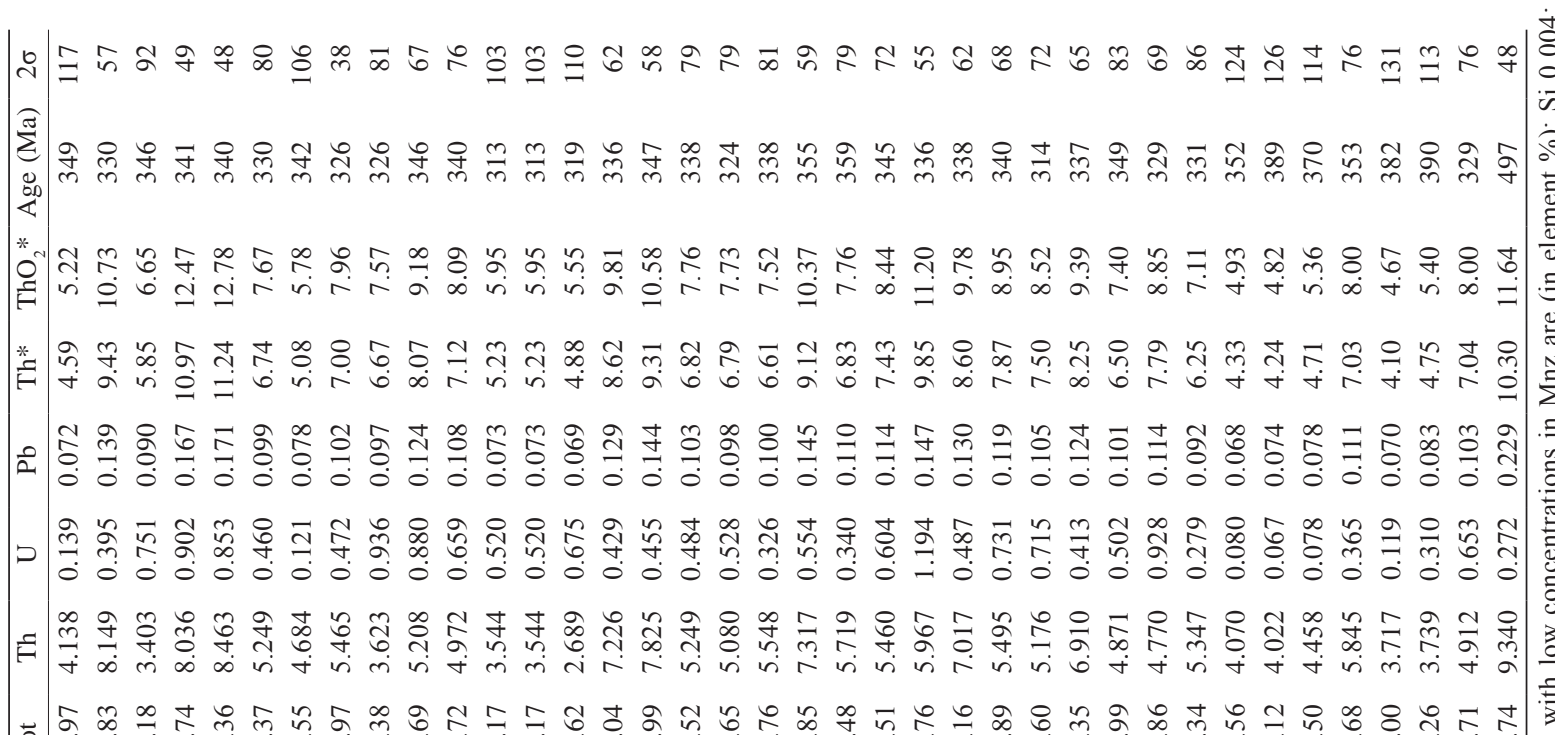

॰

일

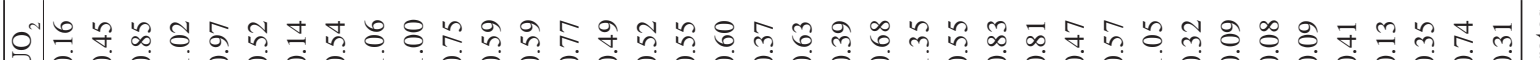

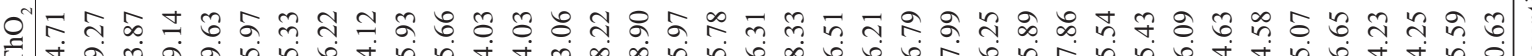

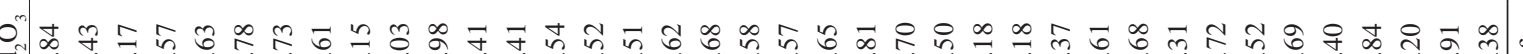

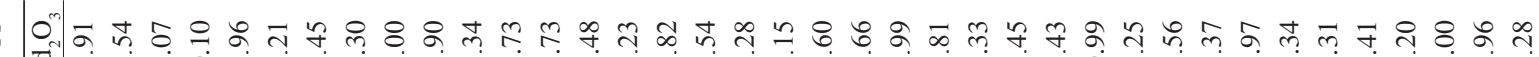

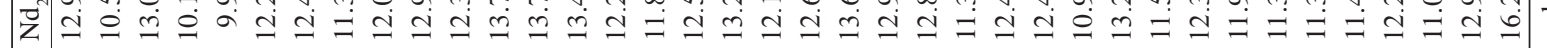

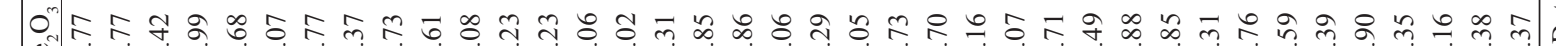

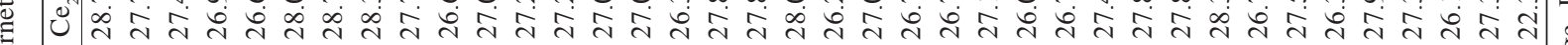

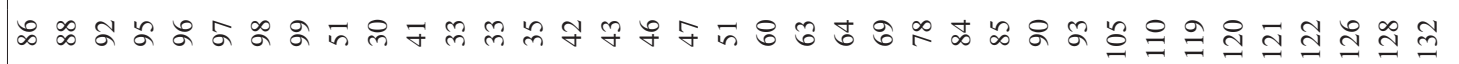

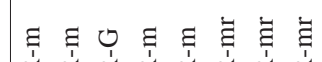



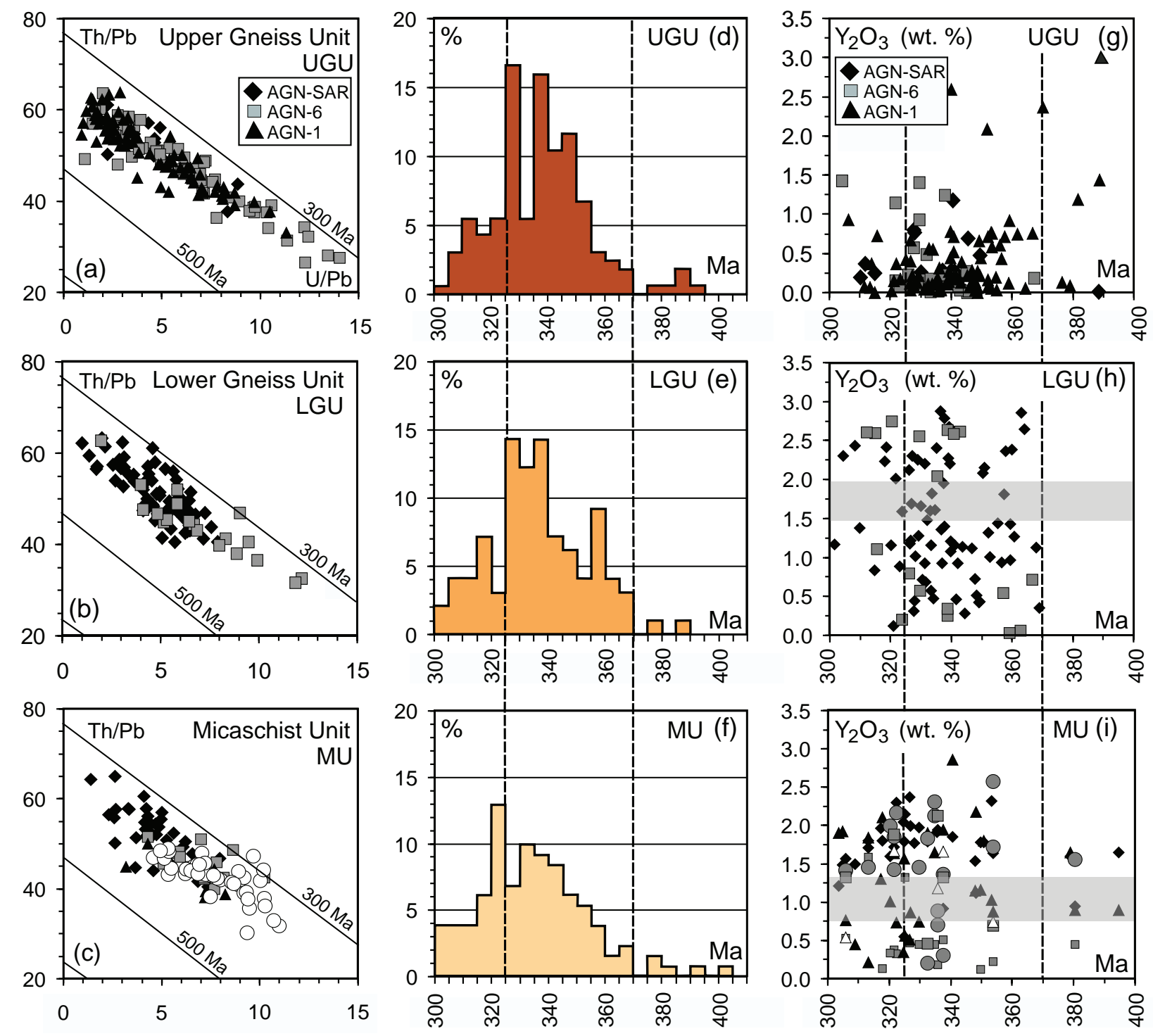

Fig. 6a-c - Chemical $\mathrm{ThO}_{2}-\mathrm{PbO}$ monazite data in the $\mathrm{U} / \mathrm{Pb}-\mathrm{Th} / \mathrm{Pb}$ diagram of Cocherie and Albarède (2001). d-f - Frequency histograms of monazite age data. Dashed lines mark limits of age distributions as discussed in the text. g-i - Binary plots of age (Ma) vs. $\mathrm{Y}_{2} \mathrm{O}_{3}$ (wt. \%) in monazites. Only a few analyses with intermediate $\mathrm{Y}_{2} \mathrm{O}_{3}$ contents occur in Lower Gneiss and Micaschist units. Most monazites in the Upper Gneiss Unit are low in $\mathrm{Y}_{2} \mathrm{O}_{3}$.

between 325 and 340 Ma displays slight differences among the nappe units (Fig. 6d-f).

Significant variations of HREE and $\mathrm{Y}$ in monazite with metamorphic grade were reported by Heinrich et al. (1997), Pyle et al. (2001), Spear and Pyle (2002) and Finger et al. (2002). As the nappe units in the HautAllier region represent an inverted metamorphic zonation (Burg 1977; Burg et al. 1984), with maximal temperatures ranging from $\sim 800^{\circ} \mathrm{C}$ in the $\mathrm{UGU}$ to $<680^{\circ} \mathrm{C}$ in the $\mathrm{MU}$ (Schulz et al. 1996), it could be tested whether the $\mathrm{Y}_{2} \mathrm{O}_{3}$ or the $X\left(\mathrm{YPO}_{4}+\mathrm{GdPO}_{4}\right)$ in monazite follow such a temperature-dependent trend. In the UGU samples, most monazites have less than $1.0 \mathrm{wt} . \% \mathrm{Y}_{2} \mathrm{O}_{3}$. Monazites with very low $\mathrm{Y}_{2} \mathrm{O}_{3}(<0.5$ wt. \%) are dominant (Fig. $6 \mathrm{~g})$. In the LGU one observes a bimodal distribution with a group at low (0.5-1.5 wt. \%) and another one at elevated (2.0-3.0 wt. \%) $\mathrm{Y}_{2} \mathrm{O}_{3}$ contents (Fig. 6h). Also in the MU a bimodal distribution can be recognised (Fig. 6i) with a dominant group of high- $\mathrm{Y}_{2} \mathrm{O}_{3}$ monazites (1.5-2.5 wt. \%). Thus, no general correlation between $\mathrm{Y}$ and also $\mathrm{X}\left(\mathrm{YPO}_{4}\right.$ $+\mathrm{GdPO}_{4}$ ) in monazite and metamorphic grade can be established in the inverted metamorphic sequence. Thus, an interpretation of monazite $\mathrm{Y}_{2} \mathrm{O}_{3}$ in terms of metamorphic temperatures alone is difficult. On the one hand, increase of $\mathrm{Y}_{2} \mathrm{O}_{3}$ in monazite should be correlated with increasing metamorphic grade when xenotime coexists (Heinrich et al. 1997). On the other hand, a low monazite Y content does not automatically indicate a low formation tempera- 
ture. It may also result from lack of Y, either because the host-rocks are Y-deficient, or because $\mathrm{Y}$ is retained by other minerals such as xenotime or (prevailing) garnet (Pyle et al. 2001). In amphibolite-facies metapelites, a major pulse of monazite growth could be linked to the decompression breakdown of garnet (Pyle and Spear 1999; Pyle et al. 2001; Fitzsimons et al. 2005; Spear 2010). The lacking correlation of monazite-Y and metamorphic grade in the studied samples could signalize that most of the monazites may have crystallized subsequent to garnet and after the thermal peak of metamorphism.

\section{Age constraints on the P-T path in the UGU}

Linking monazite ages to a $\mathrm{P}-\mathrm{T}$ path requires a detailed consideration of monazite ages and mineral chemistry, microstructures involving monazite and garnet, and the $\mathrm{P}-\mathrm{T}$ record provided by the garnet $\mathrm{Ca}-\mathrm{Mg}-\mathrm{Mn}$ evolution in low-variance assemblage. All garnets in the Agnat samples were checked by the GXMAP mode. It turned out that the Ca-rich garnet cores in the three thin sections enclosed no monazite. Monazite with ages between 310 and $360 \mathrm{Ma}$, and occasionally older grains, occur only in the Mg-rich parts of the garnets. The syncrystalline-rotated garnet in sample AGN-6 encloses numerous monazites along the curved $\mathrm{S}_{1} \mathrm{i}$ and in the pressure shadow spirals (Fig. 7a). A first assumption and interpretation could be that these monazite inclusions are older than the garnet and thus will provide an upper age limit for the onset of syntectonic garnet crystallization. However, in sample AGN-6, the ages of monazites enclosed in the large garnet vary between 309 and $338 \mathrm{Ma}$ (Figs 3h, 7a) without a distinct trend from garnet core to rim. Furthermore, the isochron calculated from the monazite inclusions provides a slightly younger age (327 $\pm 15 \mathrm{Ma}$, Fig. 5a) than the monazites from the matrix ( $338 \pm 17 \mathrm{Ma})$. The main argument that enclosed monazites did not predate the crystallization and rotation of the garnet arises from the comparison of the Y contents in garnet and monazite. In garnet, the $\mathrm{Y}$ contents decrease rimwards and this trend is matched by the $\mathrm{Y}$ contents in the enclosed monazites (Fig. 3f, h). Apart from xenotime (not present here, Tab. 1), garnet and monazite are the major $Y$ fractionating phases in metapelites (Heinrich et al. 1997; Pyle et al. 2001; Spear and Pyle 2002). As a consequence of these matching trends of $\mathrm{Y}$, monazites could not have predated the garnet but should have crystallised at the same time as the syntectonic porphyroblast. An alternative interpretation is that the enclosed monazite crystallised later than the garnet and by involving a garnet-consuming reaction. In this case, the $\mathrm{Y}_{2} \mathrm{O}_{3}$ contents in monazite mimic the $\mathrm{Y}$ zonation trend of its hosting phase. The
$\mathrm{ThO}_{2}(2.5-5.5$ wt. \%) and $\mathrm{CaO}(0.75-1.3$ wt. \%) contents in enclosed monazites increase toward the garnet rims (Fig. 3i). As $\mathrm{ThO}_{2}$ in garnet is below the detection limit of the LA-ICPMS, it appears questionable whether monazite $\mathrm{ThO}_{2}$ reflects the concentration of this element in garnet. Thus, the weighted average of $327 \pm 15 \mathrm{Ma}$ of all monazite inclusions provides the correct, or at least the minimum age for syntectonic garnet crystallization in sample AGN-6.

A different is the case of sample AGN-1: high-Y monazites with ages of $>360 \mathrm{Ma}$ (weighted average is $384 \pm 58 \mathrm{Ma}$ ) were enclosed by garnet (Fig. 7b, 8c, f). Also, a few low-Y monazites with a similar range of ages (360-390 Ma) occur in the matrix, as well in the other samples (Fig. 8a-e). They contrast with the numerous low-Y monazites of Carboniferous age (Fig. 6c-g) hosted in matrix garnet of the same sample (Fig. 8f).

As outlined above, for the $\mathrm{Y}$ fractionating phases in metapelites (Pyle et al. 2001; Spear and Pyle 2002), the Devonian high-Y monazites should have crystallized prior to, or after, garnet. As the garnet mineral-chemical evolution in the Agnat samples started at low $\mathrm{Mg}$ and high $\mathrm{Mn}$, thus at low temperatures, these old Y-rich monazites could be tentatively interpreted to mark an upper age limit for the onset of garnet crystallization.

\section{Validation of P-T-t path by numerical modeling}

While the Devonian ( $384 \pm 58 \mathrm{Ma}$ ) high-Y monazites could mark a maximal age limit, the Carboniferous $(327 \pm 15 \mathrm{Ma}$, or $\sim 330 \mathrm{Ma})$ monazites give an age for the late, syntectonic garnet in the UGU. These age limits (t) should be validated now for the inferred P-T evolution (Fig. 4d-f). Forward P-T modeling of tectonic and metamorphic histories especially in collision (Burov et al. 2001) and subduction (Gerya and Stöckhert 2006) scenarios involves a considerable list of parameters which are hampered by large uncertainties and thus need to be applied with broad variations. However, the validation of a given $\mathrm{P}-\mathrm{T}-\mathrm{t}$ evolution can be performed with less effort. The one-dimensional $\mathrm{P}-\mathrm{T}$ modeling program METAMOD by Nicollet and Bernard (1999) has been applied. It allows simulating a P-T-t evolution by variations of the geothermal gradient $(a)$, thermal diffusivity $(\kappa)$, thermal conductivity $(k)$, density $(\rho)$, vertical velocity $(U z)$ and the internal heat production $(A)$. For modeling of the P-T path in the UGU, general standard values for a continental crust as $\kappa\left(9.26 \times 10^{-7} \mathrm{~m}^{2} \cdot \mathrm{s}^{-1}\right), k$ $\left(2.5 \mathrm{~W} \cdot \mathrm{m}^{-1} \cdot \mathrm{K}^{-1}, \rho\left(2.7 \times 10^{3} \mathrm{~kg} \cdot \mathrm{m}^{-3}\right)\right.$ and $A\left(0.5 \mu \mathrm{W} \cdot \mathrm{m}^{-3}\right)$ proposed by Nicollet and Bernard (1999) have been applied and kept constant. The geothermal gradient $a$ and vertical velocity $U z$ were introduced as variables. 

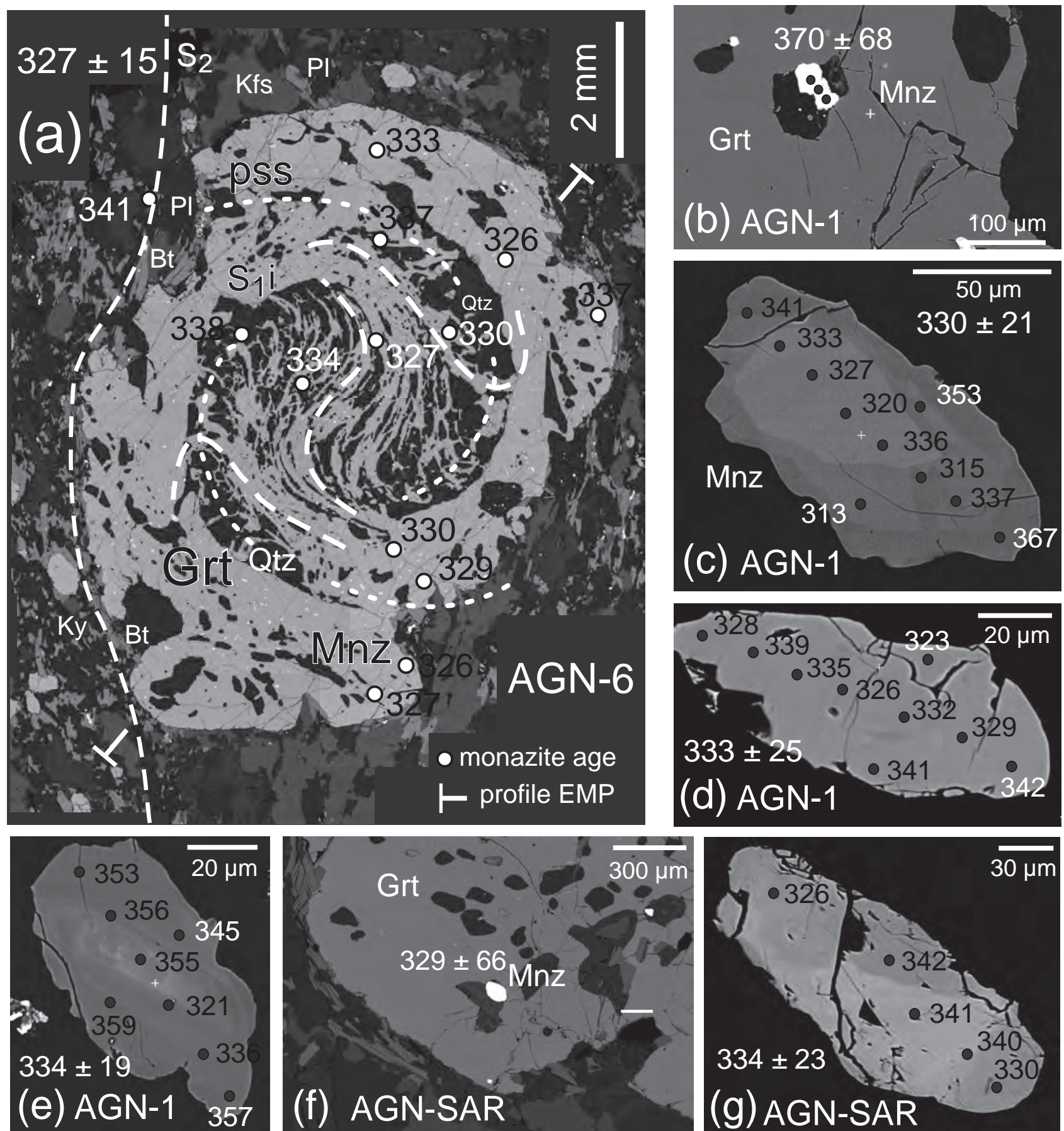

Fig. 7a - Backscattered electron images (BSE) collage of a large syntectonic garnet with numerous monazite inclusions, sample AGN-6. Monazite ages are in Ma; pressure shadow inclusion double spiral (pss) and curved internal foliation $\mathrm{S}_{1}\left(\mathrm{~S}_{1} \mathrm{i}\right)$ are marked in the garnet. Location of electron-microprobe and LA-ICPMS analytical profiles (see Fig. 3b, f) are also shown. b-g - Backscattered electron images of monazite grains in Agnat samples. Numbers mark electron-microprobe spot analyses with age in Ma; weighted average ages from the single grains were calculated according to Ludwig (2001). Compare monazites in c, g to Fig. 2c, d.

Values for the geothermal gradient were varied from 20 to $35^{\circ} \mathrm{C} / \mathrm{km}$ and increased progressively, as can be expected for clockwise $\mathrm{P}-\mathrm{T}$ paths in a continental collision accompanied by crustal thickening (England and Thompson 1984). Values for vertical velocity $U z$ were varied between $-2.4 \mathrm{~mm} /$ year for burial and $6.0 \mathrm{~mm} /$ year for uplift. The general P-T path of the Agnat samples can be subdivided into several segments (Fig. 9a-b). Each of them is characterised by the P-T conditions at its beginning and end, as marked in Fig. 9b. The pressure conditions of the segment starting point were introduced into METAMOD as recalculated depths, the temperature 

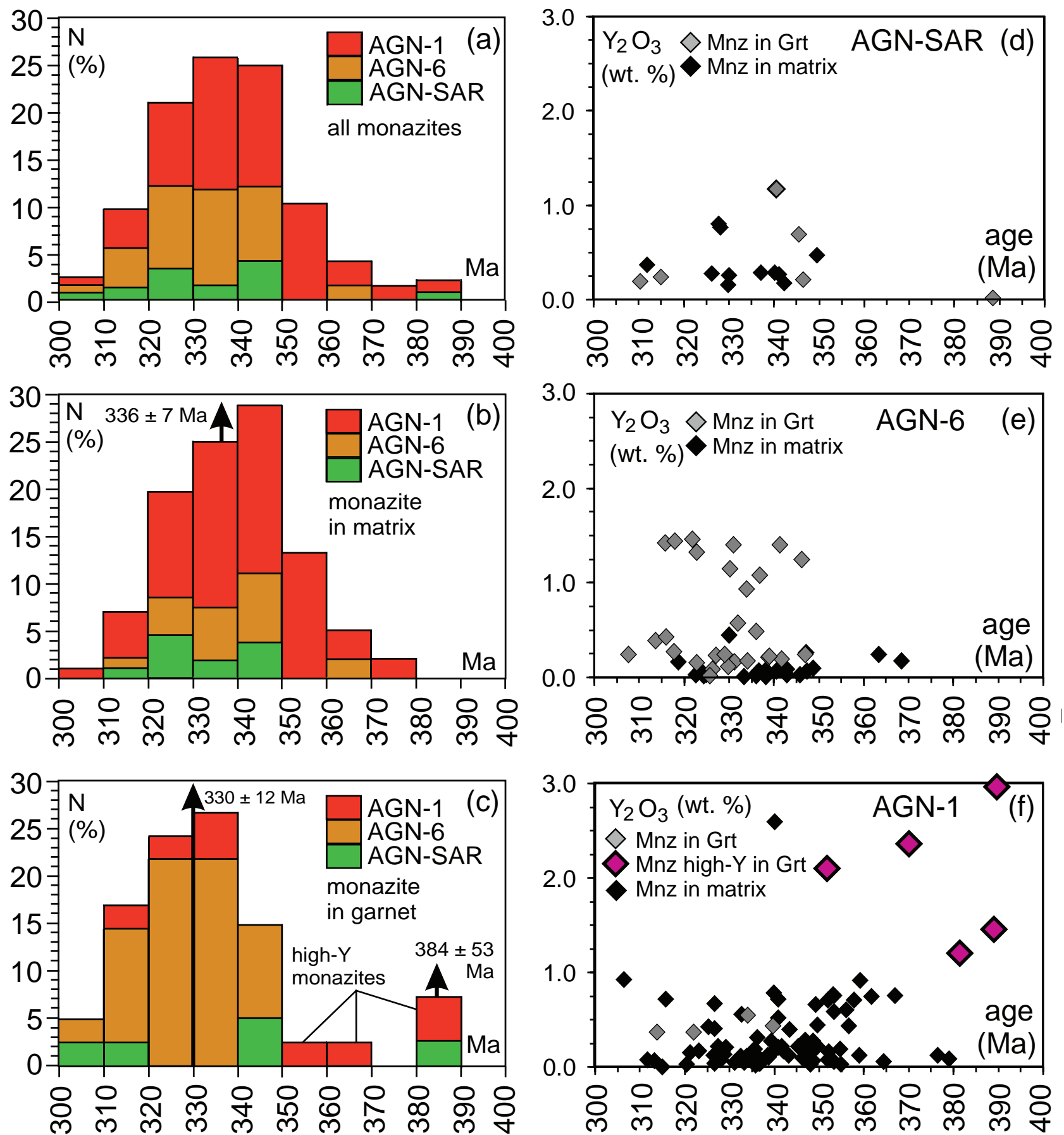

Fig. 8a-c - Frequency histograms of monazite ages in samples of kyanite garnet gneisses from Agnat, Upper Gneiss Unit. $\mathbf{d}-\mathbf{f}-$ Binary plots of age (Ma) vs. $\mathrm{Y}_{2} \mathrm{O}_{3}$ (wt. \%) in monazites. Note the monazite with high Y enclosed in garnet of sample AGN-1 (see text).

of the first segment starting point provided the initial geothermal gradient. Then, by iterative variations of the vertical velocity $U z$ and the geothermal gradient, a numerically modelled $\mathrm{P}-\mathrm{T}$ path which met the conditions of the end point of the given segment was found. That way, each segment of the observed P-T path was approximated by its modelled equivalent. The time constraints for each of these modelled $\mathrm{P}-\mathrm{T}$ path segments then were calculated by using the depths of the segment starting and end points and the corresponding vertical velocities $U z$. The durations for all $\mathrm{P}-\mathrm{T}$ path segments sum up to $\sim 36 \mathrm{Ma}$, including the final uplift/cooling (Fig. 9b). For the $\mathrm{P}-\mathrm{T}$ path sections with decompression, the time estimates are maximal. Velocities $U z$ faster than $1 \mathrm{~mm} / \mathrm{a}$ would result in a shorter time span for the initial uplift. When the monazite ages of $\sim 330 \mathrm{Ma}$ are considered to 

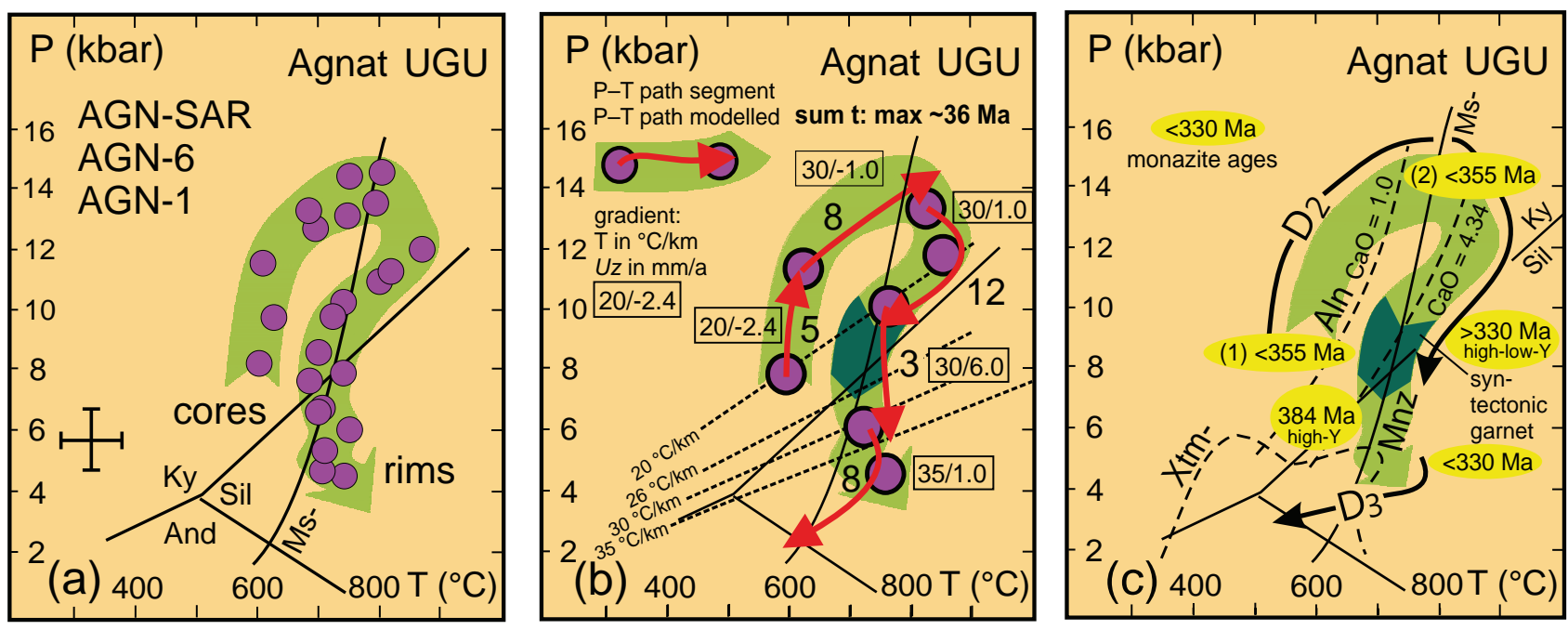

Fig. 9a -Thermobarometric data for garnet-bearing assemblage in Agnat samples (Fig. 4d-f), combined into a general P-T path for the Upper Gneiss Unit. b - Its subdivision into distinct P-T segments, each with its own starting and end points. Arrows are modelled sections of P-T paths with distinct values of geothermal gradient in ${ }^{\circ} \mathrm{C} / \mathrm{km}$ and vertical velocity in $\mathrm{mm} / \mathrm{a}$ (see text). Bold numbers are estimated time spans (My) for each segment. c - General P-T path for the UGU from garnet-bearing assemblages in Agnat samples, marked with age constraints from monazite data (see text). (1) Maximal monazite age of beginning garnet crystallization, derived from numerical P-T path modeling. (2) Maximal monazite age of high-Mg garnet crystallization as derived from phase stability fields. Stability fields of monazite and allanite at different bulk-rock CaO contents (wt. \%) according to Janots et al. (2007) and Spear (2010). The xenotime (Xtm), aluminosilicate and muscovite-out univariant lines are after Spear $(1993 ; 2010)$.

mark the age of the syntectonic garnet crystallization, the modeling implies the onset of the garnet crystallization at $\sim 355 \mathrm{Ma}$ (e.g. 330 plus $25 \mathrm{Ma}-$ Fig. 9b). Garnet crystallization could also have started later than $\sim 355$ Ma when $\mathrm{Uz}>1 \mathrm{~mm} / \mathrm{a}$ are introduced for the stage with uplift-heating followed by cooling. This modelled time frame ( $\sim 355 \mathrm{Ma})$ also coincides with the beginning of pervasive monazite crystallization at $\sim 360 \mathrm{Ma}$ in the histogram view (Fig. 6d, 8a-c). As a consequence, the interpretation of the Devonian high-Y monazites to have crystallised prior to the garnet is also confirmed. Furthermore, it is interesting to compare the $\mathrm{P}-\mathrm{T}$ path from Agnat to the stability limits and the modelled modal isopleths of monazite which are mainly controlled by the bulk Ca contents (Janots et al. 2007; Spear 2010; Spear and Pyle 2010). Even for low bulk Ca, the P-T path enters the monazite stability field at high pressures and markedly increasing temperatures (Fig. 9c). Increasing modes of monazite can be expected during subsequent uplift/heating and also uplift/cooling (Spear and Pyle 2010). This coincides with the crystallization of the Mgrich parts of garnet (Fig. 4a-d, 9c).

\section{Conclusions and implications to the Variscan metamorphic evolution}

Geothermobarometry of the garnet-bearing assemblage in kyanite garnet gneisses revealed that the UGU in the Haut-Allier region underwent burial and uplift along a clockwise P-T path. The overall shape as well as maximal pressures and temperatures of the $\mathrm{P}-\mathrm{T}$ path differ from observations in the LGU and MU (Schulz et al. 1996). These findings match data from comparable terrains in the French Massif Central (Bellot and Roig 2007). Especially from the La Sioule region to the north were reported kyanite garnet gneisses with comparable microstructures, mineral assemblages, garnet $\mathrm{Mg}-\mathrm{Ca}$ zonation trends, P-T path conditions and shapes, and monazite ages (Schulz et al. 2001; Schulz 2009). Thus, the P-T data confirm the idea of an inverted metamorphic gradient in the French Massif Central. It furthermore supports the concept of a maximal allochthony of the UGU (Burg and Matte 1978; Ledru et al. 1989, 1994).

The metamorphic evolution of the UGU at Agnat was syntectonic, as documented by inclusion trails $\mathrm{S}_{1} \mathrm{i}$ in garnet. Monazites at around 330 Ma enclosed in a syncrystalline-rotated Mg-rich garnet porphyroblast could mark a late stage of the $\mathrm{P}-\mathrm{T}$ path with isothermal decompression. The early and prograde stage of the $\mathrm{P}-\mathrm{T}$ path with crystallization of Mn- and Ca-rich garnet could be correlated to the onset of pervasive monazite crystallization at $\sim 360 \mathrm{Ma}$. Devonian high-Y monazites enclosed in the garnet should have predated this $\mathrm{P}-\mathrm{T}$ evolution (Fig. 9c). Consequently, the Agnat samples recorded an Early Carboniferous stage of the Variscan metamorphism.

Melleton et al. (2009) described monazite EMP ages of $\sim 360 \mathrm{Ma}$ from the Upper and Lower Gneiss units in the southern Limousin area to the $\mathrm{W}$ of the Sillon Houiller 
fault zone (Fig. 1a). These ages were related to a synkinematic MP/MT metamorphism coeval to top-to-NW shearing, recognised as the $\mathrm{D}_{2}$ event in the French Massif Central (Faure et al. 2009). The $360 \mathrm{Ma}$ ages (Melleton et al. 2009) were contemporaneous with the onset of monazite crystallization in the Haut-Allier region. However, the predominant 340-330 Ma monazites of the current study (Fig. 6) have not been reported from the Limousin. Thus, applying the age constraints from monazites, the $\mathrm{D}_{2}$ event in the Haut-Allier UGU should have lasted until the Viséan. Faure et al (2009) described a Viséan $\left(D_{3}\right)$ top-to-S shearing especially significant for the southern parts of the French Massif Central. At Agnat this event could have started at high temperatures in the end of the garnet crystallization and proceeded during decompression cooling (Fig. 9c). During $\mathrm{D}_{3}$, the UGU was thrusted upon the LGU and the MU.

The monazite ages and $\mathrm{P}-\mathrm{T}-\mathrm{t}$ path from Agnat do not approach the conditions (e. g. $17 \mathrm{kbar} / 700^{\circ} \mathrm{C}$ ) and the timing (430-390 Ma) of the HP-UHP, eclogite-facies event (Girardeau et al. 1986; Matte 1998; Pin and Vielzeuf 1988; Lardeaux et al. 2001; Bellot and Roig 2007; Faure et al. 2008, 2009). Therefore it can be excluded that the maximal pressure conditions of the $\mathrm{P}-\mathrm{T}-\mathrm{t}$ path reported here coincided with the Silurian HP event. Furthermore, the age constraints from monazites rule out that the syn-deformational P-T path from the kyanite garnet gneisses covered the HT conditions of the Late Devonian migmatization at $382 \pm 5 \mathrm{Ma}$ connected with uplift after a Silurian HP event (Faure et al. 1997, 2005; Cocherie et al. 2005). Merely the high-Y, $>360$ Ma old monazites in Agnat could be interpreted as remnants of such a Late Devonian event. However, during its final stage, the $\mathrm{P}-\mathrm{T}-\mathrm{t}$ path from Agnat passed the potential $\mathrm{P}-\mathrm{T}$ conditions of anatectic melting at $700-750^{\circ} \mathrm{C} / 5 \mathrm{kbar}$ (Fig. 9c). As was demonstrated by the monazite ages from the syncrystalline-rotated garnet, these anatectic conditions postdated $\sim 330 \mathrm{Ma}$ and should have corresponded to a Late Visean thermal event (post-340 Ma), as reported by Faure et al. (2002) and Couzinié et al. (2014), and already stated by Nicollet et al. (1993).

The numerical modelling of tectonic and metamorphic histories involving crustal rheologies at an active margin by Gerya and Stöckhert (2006) has demonstrated that HP-UHP conditions and Barrovian overprint can be potentially reached in an orogenic wedge above the subducting oceanic slab. This contrasts with other models which related HP-UHP conditions exclusively to continental collision (e.g. Burov et al. 2001; Chopin 2003). The numerical modelling by Gerya and Stöckhert (2006) revealed that the shapes and maximal metamorphic conditions of the P-T paths depend on the initial position of samples in a cross section through trench-accretionary wedge-continental crust wedge-mega-mélange-arc crust. Dependent on the crustal rheology, in the megamélange position with a marble-cake like structure, the models also allowed multiple P-T loops. However, the modelled multiple P-T loops occurred at considerably lower temperatures, and within less than $10 \mathrm{My}$ after the HP/UHP event, compared with Agnat (Gerya and Stöckhert 2006). Therefore it appears unlikely that the Agnat P-T-t path was part of such a multiple-loop evolution in the mega-mélange of an active margin. In contrast, the time span, the clockwise shape and the increasing geothermal gradients characterise the $\mathrm{P}-\mathrm{T}-\mathrm{t}$ path from Agnat as typical of continental collision (e.g. England and Thompson 1984). Therefore, the Variscan metamorphic evolution in the French Massif Central probably involved two separate phases: (1) the Silurian HP-UHP and the Devonian HT events that may have been related to distinct locations in an active margin evolution, involving oceanic subduction, and (2) the Early Carboniferous $\mathrm{P}-\mathrm{T}-\mathrm{t}$ path in the UGU, resulting from subsequent continental collision. Constrained by the monazite age data, the collision lasted until the Viséan. It included burial, uplift and a late HT metamorphism, top-to-WNW- and then top-to-S/SE-transporting tectonic events (Bellot and Roig 2007; Faure et al. 2009). Thus, the P-T-t data from Agnat in the UGU support a twoorogenic cycle model of the complex Variscan evolution in the French Massif Central.

Acknowledgements. The author acknowledges support by C. Audrent (Rennes), C. Triboulet (Paris), and J.-L. Feybesse (BRGM Orléans), during the Haut-Allier sampling campaign in autumn 1991. Electron-microprobe analyses at IFREMER (Brest), at the Laboratoire de Pétrologie Minéralogique, Université Pierre et Marie Curie (Paris), at Mineralogisches Institut Universität Heidelberg, at Mineralogisches Institut Universität Erlangen-Nürnberg and at Institut für Metallkunde (Freiberg) were assisted by M. Bohn, M. Fialin, H.-P. Meyer, V. von Seckendorff and D. Heger. H. Brätz (Würzburg) performed the LAICPMS analyses. Critical and constructive reviews and valuable support during the EMP monazite dating were provided by E. Krenn (Salzburg) and E. Melleton (BRGM Orléans). F. Finger and V. Janoušek are acknowledged for their editorial work on the manuscript. Automated mineralogy by SEM was possible in the Geometallurgy Laboratory at the Department of Economic Geology and Petrology, TU Bergakademie Freiberg. The Deutsche Forschungsgemeinschaft supported the studies of the author in the French Massif Central by the grants SCHU 676/3 (1991) and SCHU 676/11 (2007).

Electronic supplementary material. A table of monazite chemistries is available online at the Journal web site (http://dx.doi.org/10.3190/jgeosci.178). 


\section{References}

Ballèvre M, Bosse VV, Ducassou C, Pitra P (2009) Palaeozoic history of the Armorican Massif: models for the tectonic evolution of the suture zones. C R Geosci 341: 174-201

Bhattacharya A, Mohanty L, Maji A, Sen SK, Raith M (1992) Non-ideal mixing in the phlogopite-annite binary: constraints from experimental data on $\mathrm{Fe}-\mathrm{Mg}$ partitioning and a reformulation of the garnet-biotite geothermometer. Contrib Mineral Petrol 111: 87-93

Bellot J-P, Roig J-Y (2007) Episodic exhumation of HP rocks inferred from structural data and $\mathrm{P}-\mathrm{T}$ paths from the southwestern Massif Central (Variscan Belt, France). J Struct Geol 29: 1538-1557

Bernard-Griffiths J, Lasnier B, Marchand J (1980) Approche par la méthode $\mathrm{Rb} / \mathrm{Sr}$ de l'étude de granulites acides en Haut-Allier (Massif Central français). Réun Ann Sci Terre 8: 41

Bouchardon J-L, Santallier D, Briand B, Menot R-P, Piboule M (1989) Eclogites in the French Palaeozoic Orogen: geodynamic significance. Tectonophysics 169 : 317-332

BRÄTZ H, KLEMD R (2002) Analysis of rare earth elements in geological samples by Laser Ablation-Inductively Coupled Plasma Mass Spectrometry (LA-ICP-MS). Online publication: No. 5988-6305EN, Agilent Technologies. (http://prdwww.lvld.agilent.com/Library/ applications/5988-6305EN REE by LA.pdf)

BRIAND B (1978) Métamorphisme inverse et chevauchement de type "himalayen" dans la serie de la vallee du Lot (Massif Central français). C R Acad Sci Paris 286D: 729-731

BRUn J-P, Burg J-P (1982) Combined thrusting and wrenching in the Ibero-Armorican arc: a corner effect during continental collision. Earth Planet Sci Lett 6: 319-332

Burg J-P (1977) Tectonique et microtectonique des séries cristallophylliennes du Haut-Allier et de la vallée de la Truyère. Thèse 3 e cycle, Université de Montpellier, pp $1-106$

Burg J-P, Matte P (1978) A cross-section through the French Massif Central and the scope of its Variscan geodynamic evolution. Z Dtsch geol Gesell 129: 429-460

Burg J-P, Leyreloup A, Marchand J, Matte P (1984) Inverted metamorphic zonation and large scale thrusting in the Variscan belt; an example in the French Massif Central. In: Hutton DHW, SAnderson DJ (eds) Variscan Tectonics of the North Atlantic Region. Geological Society of London Special Publications 14: 47-61

Burg J-P, Bale P, BRun J-P, GirardeAu J (1987) Stretching lineation and transport direction in the Ibero-Armorican arc during the Siluro-Devonian collision. Geodin Acta 1: 71-87
Burg J-P, Delor CP, Leyreloup AF, Romney F (1989) Inverted metamorphic zonation and Variscan thrust tectonics in the Rouergue area (Massif Central, France): $\mathrm{P}-\mathrm{T}-\mathrm{t}$ record from mineral to regional scale. In: DALY JS, CLIFF RA, YARdLey BWD (eds) Evolution of Metamorphic Belts. Geological Society of London Special Publications 43: pp 423-439

Burov E, Jolivet L, Le Pourhiet L, Poliakov A (2001) A thermomechanical model of high pressure (HP) and ultra-high pressure (UHP) metamorphic rocks in Alpinetype collision belts. Tectonophysics 342: 113-136

CHopin C (2003) Ultrahigh pressure metamorphism: tracing continental crust into the mantle. Earth Planet Sci Lett 132: $225-232$

Cocherie A, Albarède F (2001) An improved U-Th-Pb age calculation for electron microprobe dating of monazite. Geochim Cosmochim Acta 65: 4509-4522

Cocherie A, Legendre O, Peucat J J, Koumelan AN (1998) Geochronology of polygenetic monazites constrained by in-situ microprobe Th-U-total lead determination: implications for lead behaviour in monazite. Geochim Cosmochim Acta 62: 2475-2497

Cocherie A, Bé Mézème E, Legendre M, Fanning M, Faure M, Rossi P (2005) Electron microprobe dating as a tool for understanding closure of U-Th-Pb system in monazite from migmatite. Amer Miner 90: 607-618

Couzinié S, Moyen JF, Villaros A, Paquette JL, Scarrow JH, MARIGNAC C (2014) Temporal relationships between $\mathrm{Mg}-\mathrm{K}$ mafic magmatism and catastrophic melting of the Variscan crust in the southern part of Velay Complex (Massif Central, France). J Geosci 59: 69-86

Donovan JJ, Hanchar JM, Picolli PM, Schrier MD, BoatNER LA, JAROSEWICH E (2003) A re-examination of the rare-earth-element orthophosphate standards in use for electron-microprobe analysis. Canad Mineral 41: 221-232

Ducrot J, Lancelot JR, Marchand J (1983) Datation U-Pb sur zircons de l'éclogite de la Borie (Haut-Allier, France) et conséquences sur l'évolution anté-hercynienne de l'Europe occidentale. Earth Planet Sci Lett 62: 385-394

Duguet M, Le Breton N, Faure M (2007) P-T paths reconstruction of a collisional event: the example of the Thiviers-Payzac Unit in the Variscan French Massif Central. Lithos 98: 210-232

Duthou JL, Chenevoy M, Gay M (1994) Age Rb/Sr Dévonien moyen des migmatites à cordierite du Lyonnais (Massif Central français). C R Acad Sci Paris Série II 319: 791-796

England PC, Thompson AB (1984) Pressure-temperaturetime paths of regional metamorphism I. Heat transfer during the evolution of regions of thickened continental crust. J Petrol 25: 894-928

Fandrich R, Gu Y, Burrows D, Moeller K (2007) Modern SEM-based mineral liberation analysis. Int J Mineral Processing 84: 310-320 
FAure M (1995) Late Carboniferous extension in the Variscan French Massif Central. Tectonics 14: 132-153

Faure M, Grolier J, Pons J (1993) Extensional ductile tectonics of the Sioule metamorphic series (Variscan French Massif Central). Int J Earth Sci (Geol Rundsch) 82: $461-474$

Faure M, Leloix C, Roig J-Y (1997) L'évolution polycyclique de la chaîne hercynienne. Bull Soc Géol France 168-6: 695-705

Faure M, Monié P, Pin C, Maluski H, Leloix C (2002) Late Visean thermal event in the northern part of the French Massif Central: new ${ }^{40} \mathrm{Ar} /{ }^{39} \mathrm{Ar}$ and $\mathrm{Rb}-\mathrm{Sr}$ isotopic constraints on the Hercynian syn-orogenic extension. Int J Earth Sci (Geol Rundsch) 91: 53-75

Faure M, Bé Mézème E, Duguet M, Cartier C, Talbot J-Y (2005) Paleozoic tectonic evolution of medio-Europa from the example of the French Massif Central and Massif Armoricain. J Virtual Expl 19: Paper 5

Faure M, Bé Mézème E, Cocherie A, Rossi P, Chemenda A, Boutelier D (2008) Devonian geodynamic evolution of the Variscan Belt, insights from the French Massif Central and Massif Armoricain. Tectonics 27: TC2005, doi:10.1029/2007TC002115

Faure M, Lardeaux J-M, Ledru P (2009) A review of the pre-Permian geology of the Variscan French Massif Central. C R Geosci 341: 202-213

Finger F, Helmy HM (1998) Composition and total-Pb model ages of monazite from high-grade paragneisses in the Abu Swayel area, southern Eastern Desert, Egypt. Mineral Petrol 62: 269-289

Finger F, Krenn E, Riegler G, Romano S, Zulauf G (2002) Resolving Cambrian, Carboniferous, Permian and Alpine monazite generations in the polymetamorphic basement of eastern Crete (Greece) by means of the electron microprobe. Terra Nova 14: 233-240

Fitzsimons JCW, Kinny PD, Wetherley S, Hollingsworth DA (2005) Bulk chemical control on metamorphic monazite growth in pelitic schists and implications for $\mathrm{U}-\mathrm{Pb}$ age data. J Metamorph Geol 23: 261-277

Foster G, Kinny P, Vance D, Prince C, Harris N (2000) The significance of monazite $\mathrm{U}-\mathrm{Th}-\mathrm{Pb}$ age data in metamorphic assemblages; a combined study of monazite and garnet chronometry. Earth Planet Sci Lett 181: 327-340

Friedrich M, MarignaC C, FLOC'H J-P (1988) Sur l'existence de trois chevauchements ductiles "himalayens" successifs à vergence NW en Limousin. C R Acad Sci Paris Série II 306: 663-669

Gaidies F, Krenn E, de Capitani C, Abart R (2008) Coupling forward modelling of garnet growth with monazite geochronology: an application to the Rappold Complex (Austroalpine crystalline basement). J Metamorph Geol 26: 775-793

Ganguly J, Cheng W, Tirone M (1996) Thermodynamics of aluminosilicate garnet solid solution: new experimental data, an optimized model, and thermometric applications. Contrib Mineral Petrol 123: 137-151

Gerya T, StÖCKhert B (2006) Two-dimensional numerical modeling of tectonic and metamorphic histories at active continental margins. Int J Earth Sci 95: 250-274

Girardeau J, Dubuisson G, Mercier JCC (1986) Cinématique de mise en place des ophiolites et nappes cristallophylliennes du Limousin, Ouest du Massif Central français. Bull Soc Géol France 8: 849-860

Heinrich W, Andrehs G, Franz G (1997) Monazite-xenotime miscibility gap thermometry. I. An empirical calibration. J Metamorph Geol 15: 3-16

HoldAWAY M J (2001) Recalibration of the GASP geobarometer in light of recent garnet and plagioclase activity models and versions of the garnet-biotite geothermometer. Amer Miner 86: 1117-1129

Holland T JB, Powell R (1990) An enlarged and updated internally consistent thermodynamic dataset with uncertainties and correlations: the system $\mathrm{K}_{2} \mathrm{O}-\mathrm{Na}_{2} \mathrm{O}-\mathrm{CaO}-$ $\mathrm{MgO}-\mathrm{MnO}-\mathrm{FeO}-\mathrm{Fe}_{2} \mathrm{O}_{3}-\mathrm{Al}_{2} \mathrm{O}_{3}-\mathrm{TiO}_{2}-\mathrm{SiO}_{2}-\mathrm{C}-\mathrm{H}_{2}-\mathrm{O}_{2}$. J Metamorph Geol 8: 89-124

JACKSOn SE, LONGerich HP, Dunning GR, Fryer BJ (1992) The application of laser ablation microprobe-inductively coupled plasma-mass spectrometry (LAM-ICP-MS) to in situ trace element determination in minerals. Canad Mineral 30: 1049-1064

Janots E, Brunet F, Goffé B, Poinssot C, Burchard M, CEmic L (2007) Thermochemistry of monazite-(La) and dissakisite-(La): implications for monazite and allanite stability in metapelites. Contrib Mineral Petrol 154: $1-14$

JAROSEWICH E, BOATNER LA (1991) Rare-earth element reference samples for electron microprobe analysis. Geostand Newsl 15: 397-399

JERCINOVIC MJ, WiLliams ML, LANE ED (2008) In-situ trace element analysis of monazite and other fine-grained accessory minerals by EMPA. Chem Geol 254: 197-215

KRETz R (1983) Symbols for rock-forming minerals. Amer Miner 68: 277-279

Kroner U, Romer RL (2013) Two plates - many subduction zones: the Variscan orogeny reconsidered. Gondwana Res 24: 298-329

Lardeaux J-M, Ledru P, Daniel I, Duchène S (2001) The Variscan French Massif Central - a new addition to the ultra-high pressure metamorphic “club”: exhumation processes and geodynamic consequences. Tectonophysics 332: 143-168

Ledru P, Lardeaux J-M, Santallier D, Autran A, Quenardel J-M, Floc'h J-P, Lerouge, G, Maillet N, Marchand J, Ploquin A (1989) Où sont les nappes dans le Massif Central français? Bull Soc Géol France 1989/8: 605-618

Ledru P, Costa S, Echtler H (1994) The Massif Central. Structure. In: KePpIE JD (ed) Pre-Mesozoic Geology 
in France and Related Areas. Springer, Heidelberg, pp 305-323

LUDWIG KR (2001) User's manual for Isoplot/Ex rev. 2.49. A geochronological toolkit for Microsoft Excel. Berkeley Geochronology Center Special Publications 1a: 1-55

MalavieIlle J (1993) Late orogenic extension in mountain belts: insights from the Basin and Range and the latePaleozoic Variscan belt. Tectonics 12: 1115-1130

Malavieille J, Guinot P, Costa S, Lardeaux J-M, Gardien V (1990) Collapse of the thickened Variscan crust in the French Massif Central: Mont Pilat extensional shear zone and St. Etienne Late Carboniferous basin. Tectonophysics 177: 139-149

Marchand J (1974) Persistance d'une serie granulitique au coeur du Massif Central français (Haut-Allier). Les thermes acides. Thèse 3è cycle, Université Nantes, pp $1-267$

Marchand J, Cornen G, Burg JP, Lasnier B, Leyreloup A (1985) Carte géol. France 1:50 000, feuille Langeac (790). BRGM Orléans

Marchand J, Bouillier JP, Burg JP, Cornen G, et al. (1989) Note éxplicative, Carte géol. France 1:50 000, feuille Langeac (790). BRGM Orléans, pp 1-57

Mattauer M, Brunel M, Matte P (1988) Failles normales ductiles et grands chevauchements. Une nouvelle analogie entre l'Himalaya et la chaîne hercynienne du Massif Central français. C R Acad Sci Paris Série II 306: 671-676

Matte P (1998) Continental subduction and exhumation of HP rocks in Palaeozoic orogenic belts: Uralides and Variscides. GFF 120: 209-222

MAtтE P (2001) The Variscan collage and orogeny (480-290 $\mathrm{Ma})$ and the tectonic definition of the Armorica microplate: a review. Terra Nova 13: 117-121

Melleton J, Faure M, Cocherie A (2009) Monazite U-Th/ $\mathrm{Pb}$ chemical dating of the Early Carboniferous synkinematic MP/MT metamorphism in the Variscan French Massif Central. Bull Soc Géol France 180: 283-292

Melleton J, Cocherie A, Faure M, Rossi P (2010) Precambrian protoliths and Early Paleozoic magmatism in the French Massif Central: U-Pb data and the North Gondwana connection in the west European Variscan belt. Gondwana Res 17: 13-25

Montel J-M, Foret S, Veschambre M, Nicollet C, Provost A (1996) A fast, reliable, inexpensive in-situ dating technique: electron microprobe ages on monazite. Chem Geol 131: 37-53

Nicollet C, Bernard M (1999) Metamod: un logiciel de modélisation des trajection Pression-Température-temps $(\mathrm{P}-\mathrm{T}-\mathrm{t})$ des roches metamorphiques. Publications du CRDP d'Auvergne, Clermont-Ferrand. (http://christian. nicollet.free.fr/page/Metamod/livret/Livret.html)

Nicollet C, Lahlafi M, Lasnier B (1993) Éxistence d'un épisode granulitique de basses pressions dans Haut-Allier
(Massif Central): implications géodynamique. C R Acad Sci Paris Série II 317: 1609-1615

Paquette JL (1987) Comportement des systèmes isotopiques $\mathrm{U}-\mathrm{Pb}$ et $\mathrm{Sm}-\mathrm{Nd}$ dans le métamorphisme éclogitique. Chaîne hercynienne et chaîne alpine. Mem Doc CAESS Rennes 14: 1-189

Passchier CW, Trouw RAJ (2005) Microtectonics, $2^{\text {nd }}$ edition. Springer, Heidelberg, pp 1-289

Pearce NJG, Perkins WT, Westgate Ja, Gorton MP, JackSon SE, Neal CR, Chenery SP (1997) A compilation of new and published major and trace element data for NIST SRM 610 and NIST SRM 612 glass reference materials. Geostand Newsl 21: 115-144

Pin C, Paquette J-L (2002) Le magmatisme basique calco-alcalin d'âge dévono-dinantien du nord du Massif Central, témoin d'une marge active hercynienne: arguments géochimiques et isotopiques $\mathrm{Sr} / \mathrm{Nd}$. Geodin Acta 15: 63-77

Pin C, Peucat J-J (1986) Ages des épisodes de métamorphisme paleozoiques dans le Massif Central et le Massif Armoricain. Bull Soc Géol France 1986-2: 461-469

Pin C, Vielzeuf D (1988) Les granulites de haute pression d'Europe moyenne témoins d'une subduction éo-hercynienne. Implications sur l'origine des groupes leptynoamphiboliques. Bull Soc Géol France 1988-8: 13-20

Powell R, Holland TJB (1993) On the formulation of simple mixing models for complex phases. Amer Miner 79: $174-180$

Pyle JM, Spear FS (1999) Yttrium zoning in garnet: coupling of major and accessory phases during metamorphic reactions. GMR 1: 1-49

Pyle JM, Spear FS, Rudnick RL, McDonough WF (2001) Monazite-xenotime-garnet equilibrium in metapelites and a new monazite-garnet thermometer. J Petrol 42: 2083-2107

Pyle JM, Spear FS, Wark DA, Daniel CG, Storm LC (2005) Contributions to precision and accuracy of chemical ages of monazite. Amer Miner 90: 547-577

Quenardel J-M, Santallier D, Burg J-P, Brill H, CatheLineau M, Marignac C (1991) Le Massif Central. Sci Géol Bull 44: 105-206

RoIG J-Y, FAURE M (2000) La tectonique cisaillante polyphasée du Sud-Limousin (Massif Central français) et son interprétation dans un modèle d'évolution polycyclique de la chaîne hercynienne. Bull Soc Géol France 171: 295-307

Rolin P, Quenardel J-M (1980) Nouvelle interprétation du renversement de la série cristallophyllienne du Plateau d'Aigurande (NW du Massif Central français). C R Acad Sci Série II 290: 17-20

Santallier DS, Lardeaux J-M, Marchand J, Marignac C (1994) The Massif Central. Metamorphism. In: KepPIE JD (ed) Pre-Mesozoic Geology in France and Related Areas. Springer, Berlin-Heidelberg, pp 324-340 
Schoneveld C (1977) A study of some typical inclusion patterns in strongly paracrystalline-rotated garnets. Tectonophysics 39: 453-471

Schulz B (1993) P-T-deformation paths of Variscan metamorphism in the Austroalpine basement: controls on geothermobarometry from microstructures in progressively deformed metapelites. Swiss Bull Mineral Petrol 73: 301-318

Schulz B (1995) Rekonstruktion von P-T-t-d-Pfaden der Metamorphose: Mikrostrukturell kontrollierte Geothermobarometrie in Metapeliten und Metabasiten der variskischen Internzone (Ostalpen, Nordost-Bayern, Aiguilles Rouges Massif, Massif Central). Erlanger Geol Abh 126: pp 1-222

Schulz B (2009) EMP-monazite age controls on P-T paths of garnet metapelites in the Variscan inverted metamorphic sequence of La Sioule, French Massif Central. Bull Soc géol France 180: 171-182

Schulz B, Schüssler U (2013) Electron-microprobe Th-U-Pb monazite dating in Early-Paleozoic high-grade gneisses as a completion of $\mathrm{U}-\mathrm{Pb}$ isotopic ages (Wilson Terrane, Antarctica). Lithos 175-176: 178-192

Schulz B, von Raumer JF (2011) Discovery of OrdovicianSilurian metamorphic monazite in garnet metapelites of the Alpine External Aiguilles Rouges Massif. Swiss J Geosci 104: 67-79

Schulz B, Triboulet C, Audren C, Feybesse J-L (1996) Zoned garnets in metapelites and $\mathrm{P}-\mathrm{T}$-deformation path interpretation of the Variscan inverted metamorphic sequence of Haut-Allier, French Massif Central. Z Dtsch geol Gesell 147: 249-273

Schulz B, Triboulet C, Audren C, Feybesse J-L (2001) P-T paths from metapelite garnet zonations, and crustal stacking in the Variscan inverted metamorphic sequence of La Sioule, French Massif Central. Z Dtsch geol Gesell 152: 1-25

Schulz B, Brätz H, Bombach K, Krenn E (2007) In-situ $\mathrm{Th}-\mathrm{Pb}$ dating of monazite by $266 \mathrm{~nm}$ laser ablation and ICP-MS with a single collector, and its control by EMP analysis. Z Angew Geol 35: 377-392

Schulz B, Sandmann D, Haser S, Gutzmer J (2012) Creation of semiquantitative mineral-chemical zonation maps of garnet porphyroblasts by automated SEM-EDS analysis in polymetamorphic micaschists. In: PANGEO AUSTRIA 2012, Abstracts. Universität Salzburg, pp $1-126$

Spear FS (1993) Metamorphic Phase Equilibria and Pressure-Temperature-Time Paths. Mineralogical Society of America Monograph Series, Washington, pp 1-799

SpeAR FS (2010) Monazite-allanite phase relations in metapelites. Chem Geol 279: 55-62

Spear FS, Pyle JM (2002) Apatite, monazite and xenotime in metamorphic rocks. In: KoHn M, Rakovan J, Hughes JM (eds) Phosphates - Geochemical, Geobiological and Materials Importance. Mineralogical Society of America and Geochemical Society Reviews in Mineralogy and Geochemistry 48: pp 293-335

Spear FS, Pyle JM (2010) Theoretical modeling of monazite growth in a low-Ca metapelite. Chem Geol 273: 111-119

Spear FS, Kohn MJ, Florence FP, Menard T (1990) A model for garnet and plagioclase growth in pelitic schists: implications for thermobarometry and P-T path determinations. J Metamorph Geol 8: 683-696

Spear FS, Pyle JM, Cherniak D (2009) Limitations of chemical dating of monazite. Chem Geol 266: 218-230

Suzuki K, Kato T (2008) CHIME dating of monazite, xenotime, zircon and polycrase: protocol, pitfalls and chemical criterion of possible discordant age data. Gondwana Res 14: 569-586

Suzuki K, Adachi M, KaJizuka I (1994) Electron microprobe observations of $\mathrm{Pb}$ diffusion in metamorphosed detrital monazites. Earth Planet Sci Lett 128: 391-405

Triboulet C, Audren C (1985) Continuous reactions between biotite, garnet, staurolite, kyanite-sillimanite-andalusite and $\mathrm{P}-\mathrm{T}$-time-deformation path in micaschists from the estuary of the river Vilaine, South Brittany, France. J Metam Geol 3: 91-105

Wu CM, Cheng BH (2006) Valid garnet-biotite (GB) geothermometry and garnet-aluminium silicate-plagioclase-quartz (GASP) geobarometry in metapelitic rocks. Lithos 89: 1-231 